\title{
What Do Private Firms Look like? ${ }^{* \dagger}$
}

\section{Data Appendix to “Does the Stock Market Distort Investment Incentives?”}

\author{
John Asker \\ Stern School of Business \\ New York University \\ and NBER
}

\author{
Joan Farre-Mensa \\ Department of Economics \\ New York University
}

\author{
Alexander Ljungqvist \\ Stern School of Business \\ New York University \\ ECGI and CEPR
}

March 28, 2011

\footnotetext{
* We are grateful to Sageworks Inc. for access to their database on private companies, and to Drew White and Tim Keogh of Sageworks for their help and advice regarding their data. The authors gratefully acknowledge generous financial support from the Ewing Marion Kauffman Foundation under the Berkley-Kauffman Grant Program.

${ }^{\dagger}$ Address for correspondence: New York University, Stern School of Business, Suite 9-160, 44 West Fourth Street, New York NY 10012-1126. Phone 212-998-0304. Fax 212-995-4220. e-mail al75@nyu.edu.
} 


\title{
What Do Private Firms Look like?
}

\section{Data Appendix to “Does the Stock Market Distort Investment Incentives?”}

\begin{abstract}
Private firms in the U.S. are not subject to public reporting requirements, so relatively little is known about their characteristics and behavior - until now. This Data Appendix describes a new database on private U.S. firms, created by Sageworks Inc. in cooperation with hundreds of accounting firms. The contents of the Sageworks database mirror Compustat, the standard database for public U.S. firms. It contains balance sheet and income statement data for 95,297 private firms covering 250,507 firms-years over the period 2002 to 2007. We compare this database to the joint Compustat-CRSP database of public firms and to the Federal Reserve's 2003 National Survey of Small Business Finances.
\end{abstract}




\section{A1. Overview}

Private firms in the U.S. are not subject to public reporting requirements, so relatively little is known about their characteristics and behavior - until now. This Data Appendix describes a new database on private U.S. firms, created by Sageworks Inc. in 2000 in cooperation with hundreds of accounting firms. The contents of the Sageworks database mirror Compustat, the standard database for public U.S. firms. It contains balance sheet and income statement data for 95,297 private firms over the period 2002 to 2007.

Like Compustat, Sageworks contains accounting data from income statements and balance sheets and basic demographic information such as NAICS industry codes and geographic location. There are three main differences to Compustat: 1) Sageworks covers almost exclusively private firms, ${ }^{1}$ while Compustat covers stock-market listed firms as well as firms traded over-the-counter (along with some backfilled, preIPO data for firms that went public on a U.S. stock exchange); 2) Sageworks contains no data from the cash flow statement or from the footnotes to the financial statements; and 3) and unlike in Compustat, all data in Sageworks are held anonymously so that no individual firm can be identified by name.

Sageworks obtains data not from the private firms themselves, which could raise selection concerns, but from a large number of accounting firms which input data for all their corporate clients directly into Sageworks' database in an anonymous fashion. Selection thus operates at the level of the accounting firm and not of the private firms themselves. The accounting firms Sageworks co-operates with include most national mid-market accounting firms (those below the 'Big Four') and hundreds of regional players, but few of the many thousand local accountants who service the smallest firms in the economy. As a result, as we will show, the main selection effect is that firms in Sageworks are substantially larger than the small private businesses covered in the only other large-scale private-firm dataset, the Federal Reserve’s National Survey of Small Business Finances (NSSBF). This selection may be problematic depending on the application but is innocuous for the purposes of the empirical analysis in Asker, Farre-Mensa, and Ljungqvist (2010).

Sageworks is free of survivorship bias, as no records are ever deleted. Of course, if a firm goes public, dies, or switches to an accounting firm that doesn’t co-operate with Sageworks, its data time series in

\footnotetext{
${ }^{1}$ Sageworks covers a very small number of public firms, which can be filtered out.
} 
Sageworks will end, but its historical data will not be removed.

In this Data Appendix, we compare the private Sageworks firms to public Compustat firms as well as to the private firms surveyed in the Federal Reserve's most recent National Survey of Small Business Finances, conducted in 2003. We characterize both the full Sageworks sample and a matched sample used in our paper “Does the Stock Market Distort Investment Incentives?” (Asker, Farre-Mensa, and Ljungqvist (2011)).

\section{A2. Sample Construction}

Our version of the Sageworks database, which we obtained in January 2009, covers the fiscal years from 2000 through 2007. We exclude observations from 2000, as the database was in its infancy, and we keep observations from 2001 to construct lags and growth rates. Over the period 2002-2007, Sageworks contains a total of 95,297 firms and 250,507 firm-years.

Table A1 details the filters we apply. We remove 10,104 firms located in Canada and 48 firms with missing location information. This leaves 85,145 firms located in the 50 U.S. states and in the District of Columbia. Next, we remove 489 firms with missing or negative total assets and 3,441 firms with data quality problems (i.e., those violating basic accounting identities). As is customary in economic and financial research, we exclude all 8,537 firms in SIC code 6 (financial services) and 310 firms in SIC code 49 (regulated utilities). Finally, we keep only firms with at least three consecutive annual observations so that we can construct lags and still have at least two panels years of complete data, as our empirical models exploit within-firm variation. This leaves a final total of 32,204 firms and 88,568 firmyears. We refer to this as the full sample of private firms.

The construction of the public-firm sample is analogous. There are 13,961 firms in the joint CRSPCompustat database for 2002-2007. We eliminate 3,118 firms incorporated outside the U.S., 19 that do not report in U.S. dollars, 1,423 with missing or negative total assets, 1,953 financial firms, 358 regulated utilities, 207 government entities (SIC code 9), 592 firms without valid stock price quotes in CRSP, 1,313 firms that were traded somewhere other than the NYSE, AMEX, or Nasdaq (which mostly means some form of over-the-counter trading), and 82 with CRSP share codes greater than 11 (which screens out non- 
operating entities such as real estate investment trusts, mutual funds, or closed-end funds). Again keeping only firms for which we have at least two panel years of complete data leaves a sample of 3,926 public firms with 19,203 firm-years. We refer to this as the full sample of public firms.

\section{A2.1 Matching}

Not surprisingly, public firms are substantially larger than private ones. The top graph in Figure A1 shows the distribution of inflation-adjusted total assets in log 2000 dollars for each group of firms. The distributions overlap only to a limited extent. The average (median) public sample firm has total real assets of \$1,364.4 million (\$246.2 million), compared to \$7.1 million (\$1.3 million) for private firms.

Size is also the most important correlate of public status in our data. This can clearly be seen when we estimate a probit model where the dependent variable equals one if a firm is in the public-firm sample and zero if it is in the private-firm sample. Including a full set of year indicators, we find that one standard deviation increases in the explanatory variables have the following effects on the probability that a firm is public: Log total real assets: +10.6 percentage points; cash holdings: +0.52 percentage points; return on assets (ROA): -0.46 percentage points; leverage: -0.17 percentage points; and sales growth: +0.09 percentage points. The unconditional probability is $17.8 \%$, so size is the only covariate that moves the needle at all, though each of these effects is statistically significant at the 0.001 level, as are all year effects. The pseudo- $R^{2}$ of this model is $84.1 \%$.

Much of the empirical analysis in Asker, Farre-Mensa, and Ljungqvist (2010) uses a size-and-industry matched dataset. Effectively, we identify large private firms and small public firms (which are much more comparable in size) in the same industry, to neutralize the effect of variation in size and industry across Compustat and Sageworks on observed investment behavior. Our matching procedure is a variant of nearest-neighbor matching used in the program evaluation literature, surveyed in Imbens and Wooldridge (2009). The matched dataset is essentially drawn from the region where the two size distributions shown in Figure A1 overlap. It is constructed as follows. Starting in 2002, for each public firm, we identify the private firm in the same four-digit NAICS industry and fiscal year closest in terms of total assets (TA) such that $\max \left(T A_{\text {public }}, T A_{\text {private }}\right) / \min \left(T A_{\text {public }}, T A_{\text {private }}\right)<2$. If no match can be found in a given fiscal 
year, the observation is discarded and a new match is attempted for that firm in the following year. Once a match is formed, it is kept intact for as long as both the public and private firms remain in our sample, to maximize the available time series for each firm. If a matching firm exits the panel, a new match is spliced in. The matched sample contains 4,975 public-firm-years and an equal number of private-firmyears. Because we match with replacement, to maximize the match rate, the matched sample contains 1,666 public firms and 620 private firms.

The matched sample is much more balanced in terms of firm size. The bottom graph in Figure A1 shows the distribution of log real assets for public and private firms in the matched sample. The overlap is near perfect. The means are \$144.7 million and \$120.0 million for public and private firms, respectively, and the difference between them is not statistically significant at the $5 \%$ level.

To put the matching into perspective, Figure A2 shows a breakdown of the public firm-years in our matched sample by CRSP size deciles. Almost $80 \%$ of matched firm-years are in CRSP decile 10, the smallest publicly traded firms, with another $11.6 \%$ in decile 9.

Table A2 provides a distribution by year of the full samples of 3,926 Compustat and 32,204 Sageworks firms and the matched samples of 1,666 Compustat and 620 Sageworks firms, as well as entry and exit into each panel.

\section{A2.2 The 2003 National Survey of Small Business Finances}

The National Survey of Small Business Finances collects information on small businesses in the United States by interview. The information collected includes firm size, owner characteristics, use of financial services, and the income and balance sheets of the firms. The survey is conducted for the Board of Governors of the Federal Reserve System and is available for the years 1987, 1993, 1998, and 2003. The full public datasets, together with methodology reports, codebooks, and other related documentation, are available at http://www.federalreserve.gov/pubs/oss/oss3/nssbftoc.htm.

We focus our analysis on the 2003 NSSBF, the most recent one available. The 2003 NSSBF provides information about a nationally representative sample of small U.S. businesses. The target population is the population of all for-profit, nonfinancial, nonfarm, nonsubsidiary business enterprises that had fewer than 
500 employees and were in operation as of year-end 2003 and on the date of the interview (around 6.3 million firms). Most firms’ interviews took place between June and December in 2004.

The dataset contains information on an anonymous sample of 4,240 small businesses, sampled from the Dun's Market Identifier file as of May 2004. The sample is designed as a stratified random sample with over-sampling to ensure that statistics can be reliably estimated by various employment size groups. Statistics representative of the population of the 6.3 million small businesses in the U.S. can be constructed using the sampling weights provided.

Unlike our Sageworks and Compustat samples, the NSSBF is not a panel but a single cross-section. As a result, it is impossible to construct variables that require lags, such as sales growth or change in gross or net fixed assets (i.e., investment). While there have been four waves of surveys, firms cannot be linked across them and firms are likely different from wave to wave. Sageworks is thus the only largescale database of private U.S. companies that permits an empirical analysis of investment behaviour.

Figure A1, discussed previously, also graphs the size distribution of the firms in the 2003 NSSBF. We use the sampling weights so the distribution shown reflects the population of U.S. businesses with fewer than 500 employees. The figure shows that these firms are clearly much smaller than those in the Sageworks database, consistent with the oversampling of larger private companies implied by the tilt of Sageworks' networks of data contributors towards the larger accounting firms below the Big Four.

\section{A3. Descriptive Statistics}

\section{A3.1 Sample Distributions}

Tables A3, A4, A5, and A6 provide a distribution of the full and matched Sageworks and Compustat samples by industry (Table A3), the state in which the firm is headquartered (Table A4), legal form of organization (Table A5), and the firm's choice of accounting basis (i.e., accruals vs. cash accounting; Table A6), respectively Where available, we also provide data for the 2003 NSSBF.

\section{A3.2 Firm Age}

Figure A3 shows the distribution of log firm age in both the full and matched samples of public firms and for NSSBF firms. (Note that Sageworks does not provide data on firm age and so is omitted from the 
comparison.) The average (median) public firm in the full sample is 13.4 (8.6) years old in 2004. The average (median) public firm in the matched sample is 11.9 (9.3) years old in 2004. While we do not have age data for the Sageworks firms, it is interesting to note that public firms are younger than private firms surveyed in the 2003 NSSBF: The average (median) firm age in the NSSBF is 18.2 (15) years in 2004.

\section{A3.3 Ownership Structure and CEO Ownership}

Table A7 reports the distribution of CEO ownership among matched public firms based on data handcollected from proxy filings available through the SEC's EDGAR service. The table shows that publicfirm CEOs rarely hold meaningful ownership stakes in the companies they run.

Table A8 describes the ownership structure and owner-management status of all firms (Panel A) and the largest firms (Panel B) surveyed in the 2003 NSSBF. We provide overall statistics in the last column (headed “Total”) and a breakdown by legal form of organization. Most small businesses in the U.S. have a very small number of owners, so ownership is highly concentrated, and most are managed by a controlling shareholder, so ownership and control are not separated unlike in public companies.

Note that Sageworks does not provide ownership data for the firms in its database.

\section{A3.4 Summary Statistics}

Table A9 reports summary statistics for seven variables for the full samples of public and private firms (denoted 'F') and for the matched sample (denoted ' $M$ '). The variables are total real assets, gross investment, net investment, sales growth, profitability (ROA), cash holdings, and leverage. The last four columns report pairwise differences in means or medians between the relevant samples.

\section{A3.5 Conditional Summary Statistics}

The remaining tables reports breakdowns of the means of the seven variables introduced in Table A9 by fiscal year, industry, state, and legal form of organization. 


\section{References}

Asker, John, Joan Farre-Mensa, and Alexander Ljungqvist, 2011, Does the stock market distort investment incentives?, Unpublished working paper, New York University.

Fama, Eugene F., and Kenneth R. French, 1997, Industry costs of equity, Journal of Financial Economics 43, 153-193.

Ofek, Eli, and David Yermack, 2000, Taking stock: Equity-based compensation and the evolution of managerial ownership, Journal of Finance 55, 1367-1384. 
Figure A1. Firm size distribution.

This figure appears as Figure 1 in Asker, Farre-Mensa, and Ljungqvist (2010). The top graph shows the size distribution of the public and private firms in our full samples of Compustat and Sageworks firms along with the size distribution of private U.S. firms in the Federal Reserve's 2003 National Survey of Small Business Finances (NSSBF). The NSSBF is a survey of 4,240 small U.S. businesses which were interviewed between June and December 2004. The Federal Reserve supplies sampling weights to construct a nationally representative sample. We use the resulting weighted sample in all our comparisons. (We exclude 72 NSSBF firms with zero total assets and three with negative total assets.) The bottom graph shows the size distribution of the public and private firms in our matched sample. The graphs present, for each set of firms, Epanechnikov kernel densities of the natural logarithm of total assets in $\$$ millions of 2000 purchasing power. The width of the kernel density window around each point is set to 0.4. The unit of observation in the top graph is a firm (the NSSBF is a single cross-section; for public and private firms, we use the firm's first panel year). The unit of observation in the bottom graph is a firm-year, to illustrate the closeness of the matched panels.
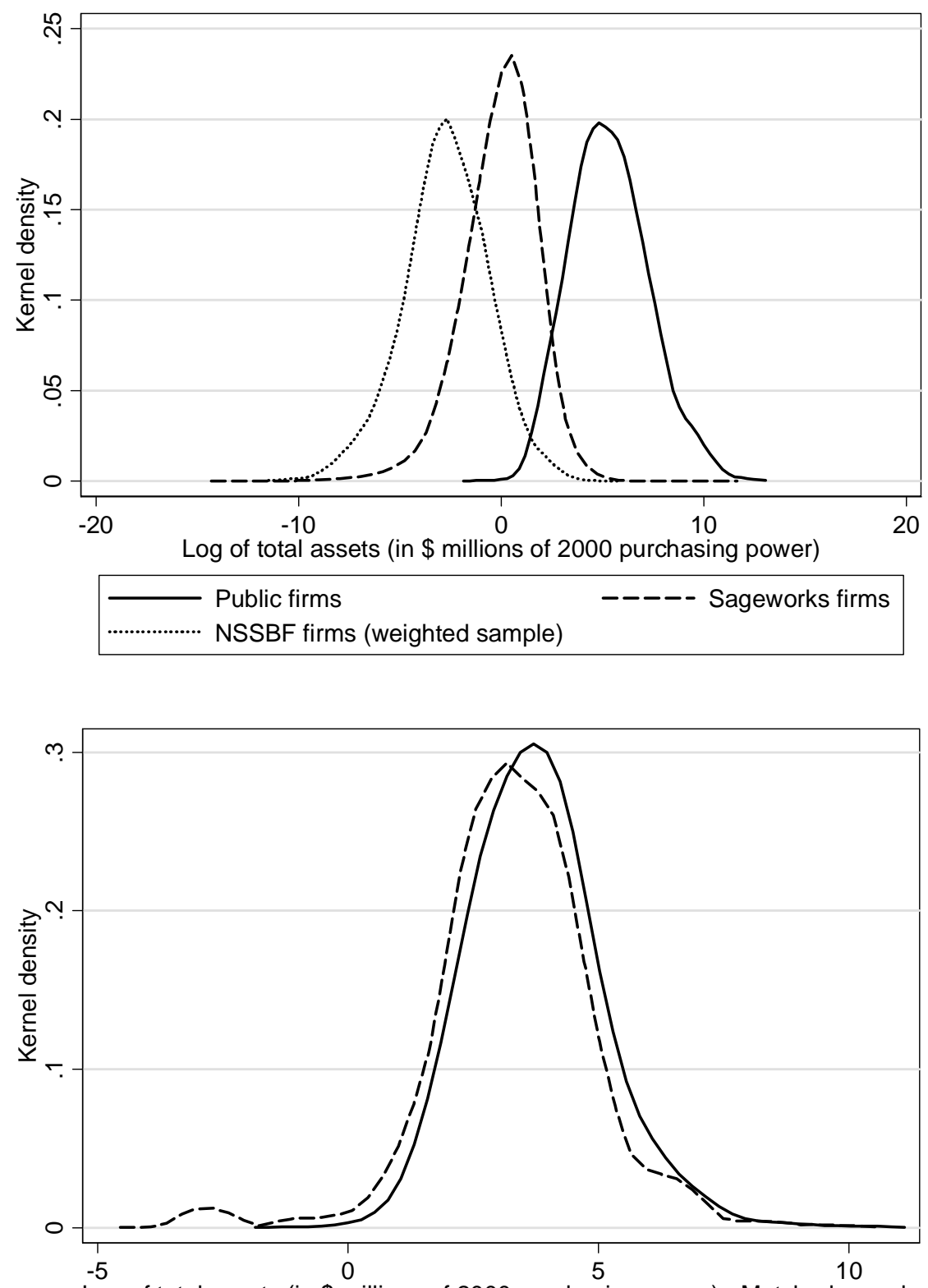

Log of total assets (in \$ millions of 2000 purchasing power) - Matched sample

\section{Public companies ----- Private companies}




\section{Figure A2. Distribution of matched public firms by CRSP size deciles.}

This figure provides a breakdown of the public firm-years in our matched sample by CRSP size deciles. Public firms are matched to private firms in the Sageworks database using the following algorithm. Starting in the first year of our sample period, for each public firm, we identify the private firm in the same industry (four-digit NAICS, equivalent to three-digit SIC) and fiscal year that is closest in terms of total assets $(T A)$. For a match to be consummated, we require $\max \left(T A_{\text {public }}, T A_{\text {private }}\right) / \min \left(T A_{\text {public }}\right.$, $\left.T A_{\text {private }}\right)$ to be less than 2 . If no match can be found in a given fiscal year, the observation is discarded and a new match is attempted for the firm in the following year. Once a match is formed, it is kept intact for as long as both the public and private firms remain in our sample, to maximize the available time series for each firm. If a matching firm exits the panel, a new match is spliced in. Matching is done with replacement. The size deciles are taken from the CRSP Quarterly Cap-based Rebalanced NYSE/AMEX/NASDAQ file (file rebalq). They are available on a quarterly basis in March, June, September, and December. Firms with a fiscal year-end from February to April are classified using the March size decile, and so on.

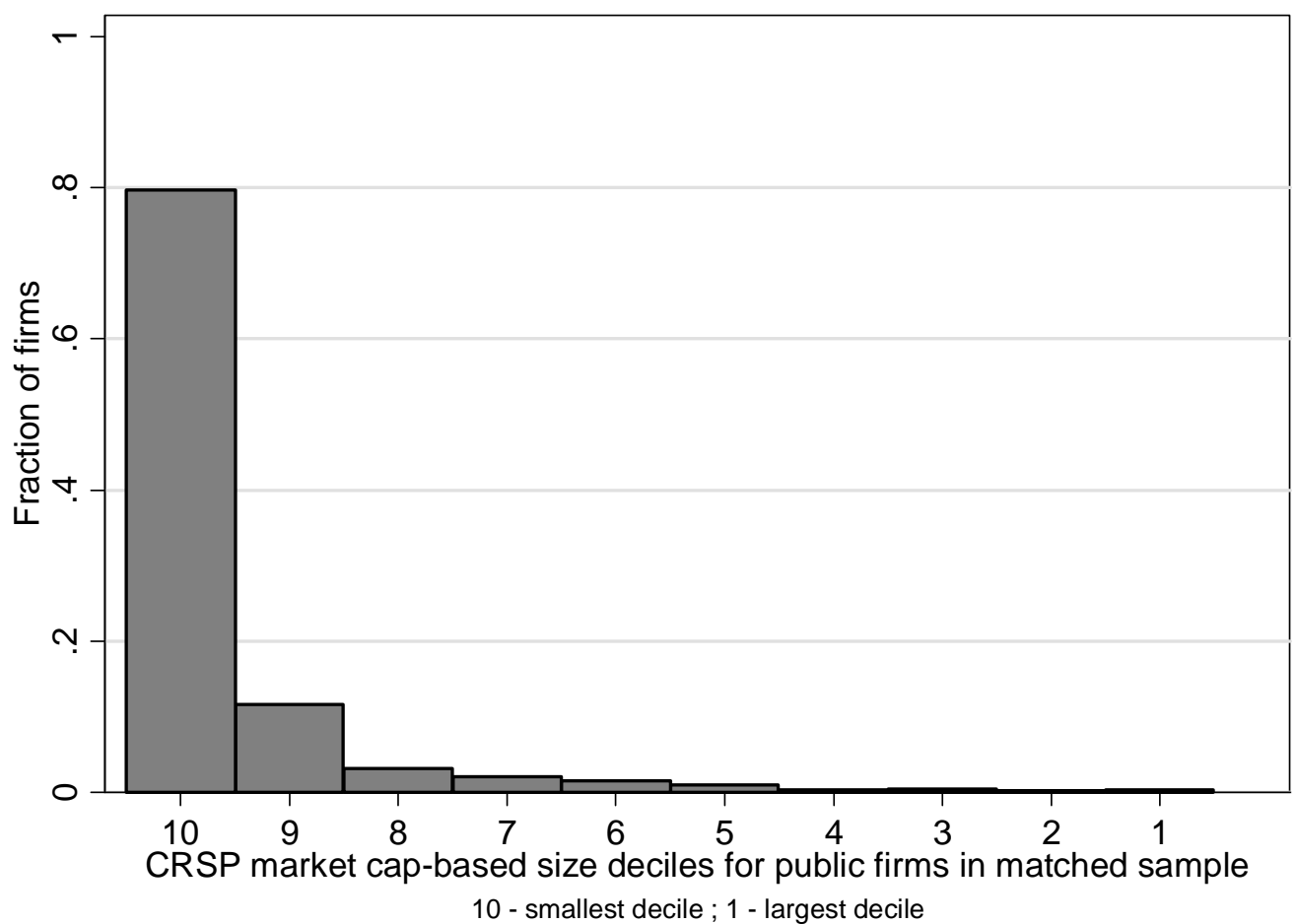




\section{Figure A3. Firm age distribution.}

This figure shows the age distribution of the public firms in our full and matched samples along with the age distribution of large private U.S. firms in the Federal Reserve's 2003 National Survey of Small Business Finances (NSSBF). (Note that age information is not available for Sageworks firms.) The NSSBF is a survey of 4,240 small U.S. businesses which were interviewed between June and December 2004. The Federal Reserve supplies sampling weights to construct a nationally representative sample. We use the resulting weighted sample in all our comparisons. Large NSSBF firms are those with 20 or more employees. In the case of NSSBF firms, age is as of the interview for the 2003 NSSBF. According to the NSSBF codebook, “The interview for most firms took place between June and December in 2004.” For comparability, we measure the age of public firms as of the end of the 2004 fiscal year if the firm was in our sample at that time and otherwise as of the end of the first fiscal year in which the firm appears in our sample. The age of a public firm is calculated as the number of years that have elapsed since the first time the firm appears with a price quote in CRSP. Given that CRSP coverage starts on December 31, 1925, by construction a public firm cannot be older than 79 years (= $2004-1925)$. The graphs present, for each set of firms, Epanechnikov kernel densities of firm age. The width of the kernel density window around each point is set to 0.5 .

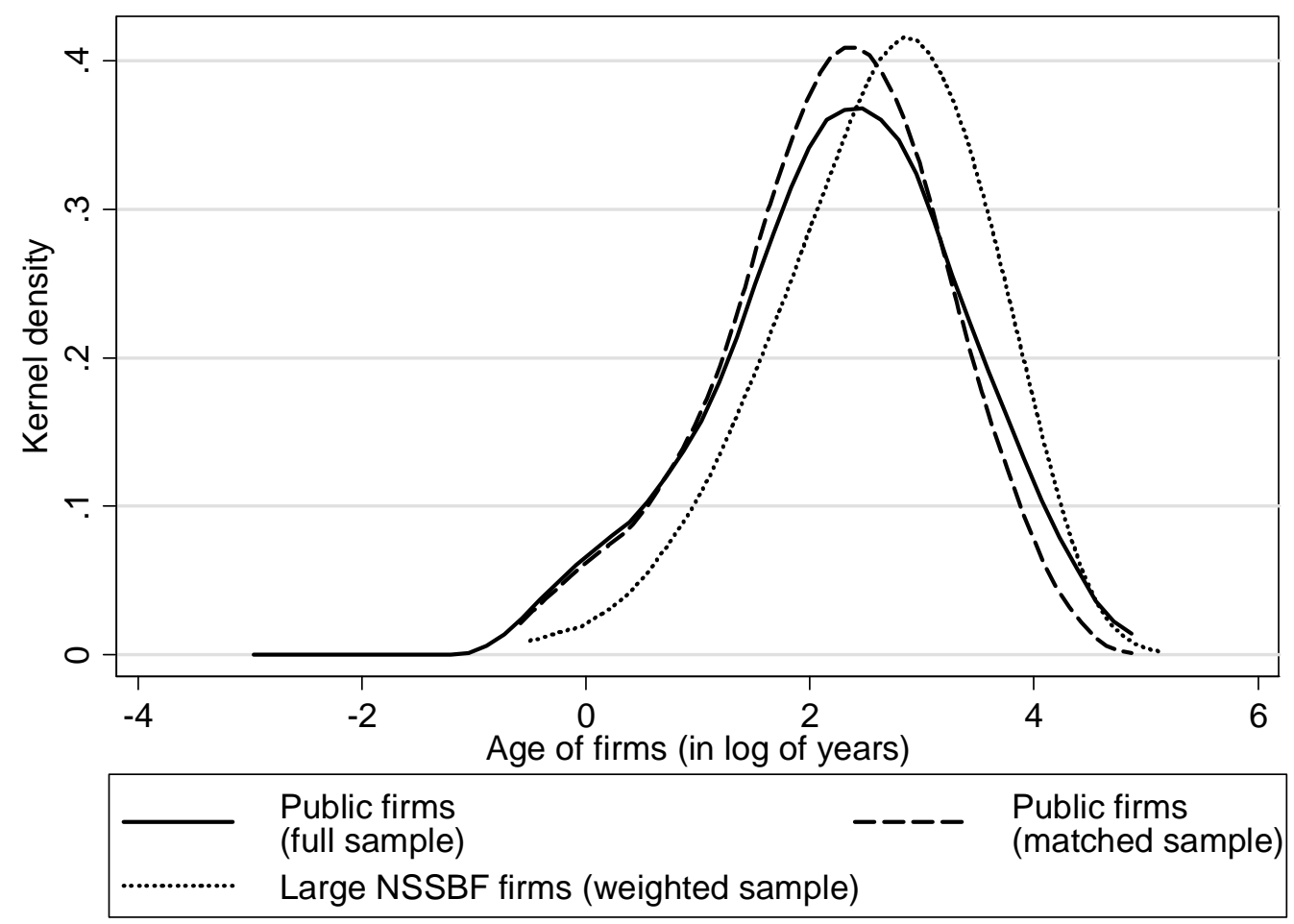


Table A1. Sample Construction.

Public firms come from Compustat. Private firms come from Sageworks. The unit of analysis in this table is a firm rather than a firm-year.

\begin{tabular}{lrr}
\hline & Public & Private \\
\hline All unique firms available in fiscal years 2002 through 2007 & 13,961 & 95,297 \\
Less: & & \\
Canadian firms & & $-10,104$ \\
Firms with location information missing & $-3,118$ & -48 \\
Firms not incorporated in the US & -19 & \\
Firms not reporting in US dollars & $-1,423$ & -489 \\
Firms with total assets missing or negative & & $-3,441$ \\
Firms with data quality problems & $-1,953$ & $-8,537$ \\
Financial firms (SIC 6) & -358 & -310 \\
Regulated utilities (SIC 49) & -207 & \\
Government entities (SIC 9) & -592 & \\
Firms not in CRSP or without a stock price & $-1,313$ & \\
Firms not listed on the NYSE, AMEX, or Nasdaq & -82 & \\
Firms with CRSP share codes $>11$ & -970 & $-40,164$ \\
Firms with fewer than three consecutive annual observations & & \\
& & \\
Final sample (“full sample") & 3,926 & \\
\hline
\end{tabular}


Table A2. Distribution by Year.

This table shows the distribution by year of the full samples of 3,926 Compustat and 32,204 Sageworks firms and the matched samples of 1,666 Compustat and 620 Sageworks unique firms used in Asker, Farre-Mensa, and Ljungqvist (2010). Our data cover the period from 2002 to 2007. The table also reports the number of firms entering and exiting each of these four samples per year. To be part of the full sample of public firms, a firm has to be recorded in both the Compustat and CRSP databases over our sample period; be incorporated in the U.S. and listed on a major U.S. exchange (NYSE, AMEX, or Nasdaq); have valid stock prices in CRSP; and have a CRSP share code of 10 or 11 (which screens out REITs, mutual funds, ADRs, etc.). The full sample of private firms is drawn from the Sageworks Inc. database of privately-held North American firms, from which we exclude Canadian firms as well as observations with data quality problems (specifically, those that fail to satisfy basic accounting identities). As is customary, we exclude from both the public and private samples financial firms (SIC 6), regulated utilities (SIC 49), and government entities (SIC 9). In addition, we exclude firms for which we have fewer than two observations with complete data for all the variables. The matched sample of public and private firms is constructed as follows: Starting in the first year of our sample period, for each public firm, we identify the private firm in the same industry (four-digit NAICS, equivalent to three-digit SIC industry) and fiscal year that is closest in terms of total assets (TA). For a match to be consummated, we require $\max \left(T A_{\text {public }}, T A_{\text {private }}\right) / \min \left(T A_{\text {public }}, T A_{\text {private }}\right)$ to be less than 2. If no match can be found in a given fiscal year, the observation is discarded and a new match is attempted for the firm in the following year. Once a match is formed, it is kept intact for as long as both the public and private firms remain in our sample, to maximize the available time series for each firm. If a matching firm exits the panel, a new match is spliced in. Matching is done with replacement. The unit of observation in this table is a firm.

\begin{tabular}{|c|c|c|c|c|c|c|}
\hline $\begin{array}{c}\text { Fiscal } \\
\text { year }\end{array}$ & $\begin{array}{c}\text { No. of } \\
\text { firms } \\
\text { per year }\end{array}$ & $\begin{array}{c}\text { No. of } \\
\text { unique } \\
\text { firms } \\
\text { entering } \\
\text { the } \\
\text { sample }\end{array}$ & $\begin{array}{c}\text { No. of } \\
\text { unique } \\
\text { firms } \\
\text { exiting } \\
\text { the } \\
\text { sample }\end{array}$ & $\begin{array}{c}\text { No. of } \\
\text { firms } \\
\text { per year }\end{array}$ & $\begin{array}{c}\text { No. of } \\
\text { unique } \\
\text { firms } \\
\text { entering } \\
\text { the } \\
\text { sample } \\
\end{array}$ & $\begin{array}{c}\text { No. of } \\
\text { unique } \\
\text { firms } \\
\text { exiting } \\
\text { the } \\
\text { sample }\end{array}$ \\
\hline & \multicolumn{6}{|c|}{ Full sample } \\
\hline & \multicolumn{3}{|c|}{ Public } & \multicolumn{3}{|c|}{ Private } \\
\hline 2002 & 3,352 & 3,352 & 0 & 2,535 & 2,535 & 0 \\
\hline 2003 & 3,426 & 112 & 239 & 6,069 & 3,589 & 470 \\
\hline 2004 & 3,293 & 110 & 269 & 13,147 & 7,663 & 1,251 \\
\hline 2005 & 3,219 & 185 & 271 & 21,611 & 9,840 & 4,029 \\
\hline 2006 & 3,134 & 167 & 368 & 26,267 & 8,577 & 7,515 \\
\hline 2007 & 2,779 & 0 & 2,779 & 18,939 & 0 & 18,939 \\
\hline \multirow[t]{3}{*}{ Total } & 19,203 & 3,926 & 3,926 & 88,568 & 32,204 & 32,204 \\
\hline & \multicolumn{6}{|c|}{ Matched sample } \\
\hline & \multicolumn{3}{|c|}{ Public } & \multicolumn{3}{|c|}{ Private } \\
\hline 2002 & 311 & 311 & 6 & 311 & 104 & 4 \\
\hline 2003 & 555 & 259 & 81 & 555 & 71 & 49 \\
\hline 2004 & 910 & 436 & 141 & 910 & 109 & 49 \\
\hline 2005 & 1,060 & 308 & 202 & 1,060 & 135 & 80 \\
\hline 2006 & 1,166 & 307 & 263 & 1,166 & 144 & 110 \\
\hline 2007 & 973 & 45 & 973 & 973 & 57 & 328 \\
\hline Total & 4,975 & 1,666 & 1,666 & 4,975 & 620 & 620 \\
\hline
\end{tabular}


Table A3. Distribution by Fama-French Industry.

This table shows the industry distribution of six samples: The full samples of 3,926 Compustat and 32,204 Sageworks firms; the matched samples of 1,666 Compustat and 620 Sageworks unique firms used in Asker, Farre-Mensa, and Ljungqvist (2010); and all firms and the largest firms surveyed in the Federal Reserve's 2003 National Survey of Small Business Finances (NSSBF). The NSSBF is a survey of 4,240 small U.S. businesses. The Federal Reserve supplies sampling weights to construct a nationally representative sample. We use the resulting weighted sample in all our comparisons. Large NSSBF firms are those with 20 or more employees. We use the Fama and French (1997) classification of 30 industry groups, available from Kenneth French's webpage. Sageworks firms are grouped into Fama-French industries based on their NAICS codes, which we map to SIC codes using the U.S. Census Bureau's NAICS-SIC bridge, available at http://www.census.gov/epcd/naics02/index.html. Compustat and NSSBF firms are grouped into FamaFrench industries according to their SIC codes (the NSSBF includes only 2-digit SIC codes). Note that Asker, Farre-Mensa, and Ljungqvist (2010) match on NAICS4 rather than Fama-French. The unit of observation is a firm rather than a firm-year. All figures in the table are in percent and sum to 100 in each column.

\begin{tabular}{|c|c|c|c|c|c|c|c|}
\hline \multirow{2}{*}{$\begin{array}{l}\mathrm{FF} \\
\text { industry }\end{array}$} & \multirow[b]{2}{*}{ Description } & \multicolumn{2}{|c|}{ Full sample (F) } & \multicolumn{2}{|c|}{ Matched sample (M) } & \multicolumn{2}{|c|}{ NSSBF weighted sample } \\
\hline & & Public & Private & Public & Private & Full & Large \\
\hline Food & Food products & 2.2 & 2.9 & 2.3 & 4.2 & 03 & 17 \\
\hline Beer & Beer \& liquor & 0.4 & 0.2 & 0.4 & 1.3 & 0.3 & 1.1 \\
\hline Smoke & Tobacco products & 0.1 & 0.0 & & & 0.0 & 0.0 \\
\hline Games & Recreation & 2.5 & 3.2 & 2.0 & 3.7 & 2.9 & 4.0 \\
\hline Books & Printing \& publishing & 1.2 & 0.9 & 1.1 & 1.3 & 1.4 & 1.5 \\
\hline Hshld & Consumer goods & 1.6 & 0.9 & 1.0 & 3.4 & 1.4 & 1.0 \\
\hline Clths & Apparel & 1.7 & 0.1 & 1.3 & 0.8 & 0.3 & 0.3 \\
\hline Hlth & Healthcare, medical equipment, pharmaceutical products & 15.0 & 4.8 & 20.0 & 9.2 & 6.5 & 9.3 \\
\hline Chems & Chemicals & 2.2 & 0.5 & 1.5 & 3.2 & 0.2 & 0.6 \\
\hline Txtls & Textiles & 0.4 & 0.1 & 0.1 & 0.3 & 0.1 & 0.2 \\
\hline Cnstr & Construction and construction materials & 2.9 & 9.1 & 2.3 & 4.2 & 13.6 & 14.8 \\
\hline Steel & Steel works etc. & 1.3 & 0.7 & 0.4 & 0.7 & 0.0 & 0.3 \\
\hline FabPr & Fabricated products and machinery & 4.1 & 2.7 & 2.9 & 4.2 & 1.7 & 4.0 \\
\hline ElcEq & Electrical equipment & 1.8 & 0.7 & 1.9 & 2.3 & 0.4 & 0.7 \\
\hline Autos & Automobiles and trucks & 1.6 & 0.4 & 1.0 & 1.3 & & \\
\hline Carry & Aircraft, ships, and railroad equipment & 0.8 & 0.2 & 0.4 & 0.8 & 0.5 & 1.1 \\
\hline Mines & Precious metals, non-metallic, and industrial metal mining & 0.4 & 0.2 & 0.1 & 0.3 & 0.0 & 0.1 \\
\hline Coal & Coal & 0.3 & 0.0 & 0.1 & 0.2 & 0.0 & 0.0 \\
\hline Oil & Petroleum and natural gas & 4.2 & 0.4 & 4.4 & 2.3 & 0.3 & 0.8 \\
\hline Telcm & Communication & 3.7 & 0.7 & 2.0 & 3.4 & 0.4 & 0.1 \\
\hline Servs & Personal and business services & 17.2 & 38.1 & 18.6 & 20.3 & 38.7 & 17.7 \\
\hline BusEq & Business equipment & 15.7 & 0.7 & 23.6 & 9.2 & 0.2 & 0.4 \\
\hline Paper & Business supplies and shipping containers & 1.5 & 0.4 & 0.8 & 1.3 & 0.0 & 0.2 \\
\hline Trans & Transportation & 2.8 & 3.0 & 1.3 & 1.8 & 3.4 & 4.1 \\
\hline Whlsl & Wholesale & 4.2 & 9.9 & 4.1 & 9.4 & 6.4 & 7.3 \\
\hline Rtail & Retail & 6.2 & 12.2 & 2.3 & 4.5 & 15.5 & 13.2 \\
\hline Meals & Restaurants, hotels, motels & 2.3 & 3.9 & 2.2 & 4.2 & 5.7 & 16.7 \\
\hline Other & Everything else & 1.9 & 3.0 & 1.9 & 2.4 & 0.1 & 0.0 \\
\hline
\end{tabular}


Table A4. Geographic Distribution.

This table shows the distribution by the state in which the firm is headquartered of the full samples of 3,926 Compustat and 32,204 Sageworks firms and the matched samples of 1,666 Compustat and 620 Sageworks unique firms used in Asker, FarreMensa, and Ljungqvist (2010). (Note that the NSSBF does not provide a breakdown by state and so is omitted from this table.) The unit of observation is a firm rather than a firm-year. All figures in the table are in percent and sum to 100 in each column.

\begin{tabular}{|c|c|c|c|c|}
\hline & \multicolumn{2}{|c|}{ Full sample (F) } & \multicolumn{2}{|c|}{ Matched sample (M) } \\
\hline & Public & Private & Public & Private \\
\hline AK & 0.1 & 0.2 & 0.0 & 0.0 \\
\hline $\mathrm{AL}$ & 0.5 & 1.6 & 0.5 & 1.3 \\
\hline AR & 0.4 & 1.1 & 0.2 & 0.2 \\
\hline $\mathrm{AZ}$ & 1.5 & 1.6 & 1.6 & 1.6 \\
\hline CA & 19.8 & 6.8 & 23.9 & 12.6 \\
\hline $\mathrm{CO}$ & 2.5 & 2.6 & 2.6 & 2.3 \\
\hline $\mathrm{CT}$ & 2.3 & 1.4 & 1.9 & 0.8 \\
\hline DC & 0.2 & 0.1 & 0.0 & 0.0 \\
\hline $\mathrm{DE}$ & 0.3 & 0.3 & 0.2 & 0.3 \\
\hline FL & 4.5 & 4.2 & 4.8 & 4.2 \\
\hline GA & 2.9 & 3.1 & 3.2 & 4.5 \\
\hline HI & 0.2 & 0.4 & 0.3 & 0.3 \\
\hline IA & 0.4 & 1.4 & 0.4 & 1.3 \\
\hline ID & 0.3 & 0.7 & 0.2 & 0.2 \\
\hline IL & 4.1 & 3.6 & 3.0 & 5.0 \\
\hline IN & 1.1 & 3.2 & 0.7 & 1.6 \\
\hline KS & 0.5 & 1.4 & 0.4 & 0.8 \\
\hline KY & 0.6 & 1.4 & 0.2 & 1.1 \\
\hline LA & 0.6 & 0.9 & 0.3 & 0.6 \\
\hline MA & 5.6 & 3.0 & 7.4 & 2.4 \\
\hline MD & 1.6 & 1.9 & 1.9 & 1.8 \\
\hline $\mathrm{ME}$ & 0.1 & 0.5 & 0.1 & 0.0 \\
\hline MI & 1.8 & 4.1 & 1.3 & 3.1 \\
\hline $\mathrm{MN}$ & 3.3 & 3.9 & 4.1 & 3.1 \\
\hline MO & 1.5 & 2.1 & 0.7 & 1.5 \\
\hline MS & 0.2 & 1.0 & 0.1 & 0.2 \\
\hline MT & 0.1 & 0.7 & 0.0 & 0.0 \\
\hline NC & 1.7 & 3.1 & 1.4 & 2.6 \\
\hline ND & 0.0 & 0.2 & 0.1 & 0.0 \\
\hline NE & 0.4 & 1.0 & 0.4 & 1.6 \\
\hline $\mathrm{NH}$ & 0.4 & 1.0 & 0.4 & 0.6 \\
\hline NJ & 4.4 & 3.4 & 4.8 & 4.2 \\
\hline NM & 0.1 & 0.4 & 0.1 & 0.2 \\
\hline NV & 0.7 & 0.7 & 0.8 & 1.1 \\
\hline NY & 7.4 & 3.7 & 7.5 & 6.3 \\
\hline $\mathrm{OH}$ & 2.9 & 5.5 & 1.8 & 4.8 \\
\hline OK & 0.7 & 0.7 & 0.8 & 1.0 \\
\hline OR & 1.1 & 1.0 & 1.4 & 2.4 \\
\hline $\mathrm{PA}$ & 4.2 & 6.3 & 3.2 & 8.4 \\
\hline RI & 0.3 & 0.3 & 0.3 & 0.3 \\
\hline SC & 0.4 & 1.3 & 0.1 & 0.3 \\
\hline SD & 0.1 & 0.5 & 0.1 & 0.0 \\
\hline $\mathrm{TN}$ & 1.5 & 1.9 & 0.7 & 1.1 \\
\hline $\mathrm{TX}$ & 8.9 & 5.9 & 7.6 & 6.6 \\
\hline UT & 0.7 & 1.5 & 1.2 & 1.1 \\
\hline VA & 2.6 & 2.1 & 2.3 & 2.1 \\
\hline VT & 0.2 & 0.3 & 0.2 & 0.2 \\
\hline WA & 2.1 & 2.6 & 2.3 & 1.5 \\
\hline WI & 1.3 & 2.6 & 0.8 & 2.3 \\
\hline WV & 0.1 & 0.4 & 0.1 & 0.5 \\
\hline WY & 0.0 & 0.4 & 0.1 & 0.2 \\
\hline Other & 0.9 & & 1.3 & \\
\hline
\end{tabular}




\section{Table A5. Distribution by Legal Form of Organization.}

This table shows the distribution by legal form of organization of six samples: The full samples of 3,926 Compustat and 32,204 Sageworks firms; the matched samples of 1,666 Compustat and 620 Sageworks unique firms used in Asker, Farre-Mensa, and Ljungqvist (2010); and all firms and the largest firms surveyed in the Federal Reserve's 2003 National Survey of Small Business Finances (NSSBF). The NSSBF is a survey of 4,240 small U.S. businesses. The Federal Reserve supplies sampling weights to construct a nationally representative sample. We use the resulting weighted sample in all our comparisons. Large NSSBF firms are those with 20 or more employees. Compustat provides no information about public firms' legal form of organization. Most public firms are C Corps. We identify non-C Corp public firms by searching company names in CRSP for "LLC", "LP”, "Limited Partnership", etc. There are two non-C Corps in the full sample and one in the matched sample. The unit of observation is a firm rather than a firm-year. All figures in the table are in percent and sum to 100 in each column.

\begin{tabular}{|c|c|c|c|c|c|c|}
\hline & \multicolumn{2}{|c|}{ Full sample (F) } & \multicolumn{2}{|c|}{ Matched sample (M) } & \multicolumn{2}{|c|}{$\begin{array}{l}\text { NSSBF weighted } \\
\text { sample }\end{array}$} \\
\hline & Public & Private & Public & Private & Full & Large \\
\hline C Corps & 99.95 & 36.5 & 99.94 & 47.6 & 14.4 & 34.9 \\
\hline S Corps & & 49.3 & & 39.5 & 31.0 & 48.5 \\
\hline Sole proprietorships & & 1.6 & & 0.5 & 42.5 & 5.2 \\
\hline Limited liability companies (LLC) & & 6.9 & & 6.8 & 5.5 & 4.4 \\
\hline Partnerships & 0.05 & 3.0 & 0.06 & 2.6 & 5.5 & 4.4 \\
\hline Limited liability partnerships (LLP) & & 0.6 & & 0.8 & 1.2 & 2.6 \\
\hline Other & & 2.2 & & 2.3 & & \\
\hline
\end{tabular}




\section{Table A6. Distribution by Accounting Basis.}

This table shows the distribution by accounting basis of six samples: The full samples of 3,926 Compustat and 32,204 Sageworks firms; the matched samples of 1,666 Compustat and 620 Sageworks unique firms used in Asker, Farre-Mensa, and Ljungqvist (2010); and all firms and the largest firms surveyed in the Federal Reserve's 2003 National Survey of Small Business Finances (NSSBF). The NSSBF is a survey of 4,240 small U.S. businesses. The Federal Reserve supplies sampling weights to construct a nationally representative sample. We use the resulting weighted sample in all our comparisons. Large NSSBF firms are those with 20 or more employees. Firms can report either on an accrual basis or on a cash basis. While Sageworks and the NSSBF provide details about the accounting basis for their respective sample of private firms, neither CRSP nor Compustat report what accounting basis public firms use. However, it is reasonable to assume that essentially all public companies use accrual accounting since all large companies in the U.S. (those with annual sales of more than $\$ 5$ million or any business holding inventory and selling more than $\$ 1$ million per year) are required to adopt accrual accounting. The unit of observation is a firm rather than a firm-year. All figures in the table are in percent and sum to 100 in each column.

\begin{tabular}{|c|c|c|c|c|c|c|}
\hline & \multicolumn{2}{|c|}{ Full sample (F) } & \multicolumn{2}{|c|}{ Matched sample (M) } & \multicolumn{2}{|c|}{$\begin{array}{l}\text { NSSBF weighted } \\
\text { sample }\end{array}$} \\
\hline & $\begin{array}{c}\text { Public } \\
\text { (estim- } \\
\text { ated) }\end{array}$ & Private & $\begin{array}{c}\text { Public } \\
\text { (estim- } \\
\text { ated) }\end{array}$ & Private & Full & Large \\
\hline Accrual basis & 100.0 & 87.1 & 100.0 & 96.8 & 24.8 & 40.9 \\
\hline Cash basis & & 8.0 & & 1.1 & 74.5 & 57.6 \\
\hline Basis unknown or not disclosed & & 4.8 & & 2.1 & 0.7 & 1.5 \\
\hline
\end{tabular}




\section{Table A7. CEO Ownership of Matched Public Firms.}

We hand-collect CEO ownership data from proxies for the first panel-year of 1,664 of the 1,666 public firms in our matched sample. (Two firms failed to file proxies or annual reports with the SEC over our sample window and hence have to be excluded.) Ownership is defined as stock held by the CEO divided by the number of shares of common stock outstanding, both measured as of the proxy date. The convention in the literature on CEO ownership is to exclude from this measure stock options exercisable within 60 days as that is how ExecuComp, the main CEO ownership database, reports ownership; see for example Ofek and Yermack (2000). We show this measure in column (1). Adding options exercisable within 60 days does not materially alter the conclusion that public-firm CEOs in our matched sample own little of their firms' equity.

\begin{tabular}{lcc}
\hline & \multicolumn{2}{c}{ CEO ownership } \\
\cline { 2 - 3 } & $\begin{array}{c}\text { without } \\
\text { options } \\
\text { exercisable } \\
\text { within } 60 \text { days } \\
(1)\end{array}$ & $\begin{array}{c}\text { with } \\
\text { options } \\
\text { exercisable } \\
\text { within } 60 \text { days }\end{array}$ \\
\hline Mean & & \\
St.dev. & 0.084 & 0.103 \\
Skewness & 0.146 & 0.150 \\
Kurtosis & 2.477 & 2.308 \\
& 9.322 & 8.526 \\
Min & & \\
5th percentile & 0.000 & 0.000 \\
10th percentile & 0.000 & 0.000 \\
25th percentile & 0.000 & 0.000 \\
50th percentile & 0.002 & 0.013 \\
75th percentile & 0.016 & 0.038 \\
90th percentile & 0.093 & 0.125 \\
95th percentile & 0.274 & 0.309 \\
Max & 0.631 & 0.479 \\
No. of firms & 0.970 & 0.971 \\
No. of firms with missing data & & \\
& 1,664 & 1,664 \\
& 2 & 2 \\
\hline
\end{tabular}


Table A8. Ownership Structure and Owner-Management Status of Private U.S. Firms.

This table describes the ownership structure and owner-management status of all firms (Panel A) and the largest firms (Panel B) surveyed in the Federal Reserve's 2003 National Survey of Small Business Finances (NSSBF). The NSSBF is a survey of 4,240 small U.S. businesses. The Federal Reserve supplies sampling weights to construct a nationally representative sample. We use the resulting weighted sample in all our comparisons. Large NSSBF firms are those with 20 or more employees. We provide overall statistics in the last column (headed "Total”) and a breakdown by legal form of organization.

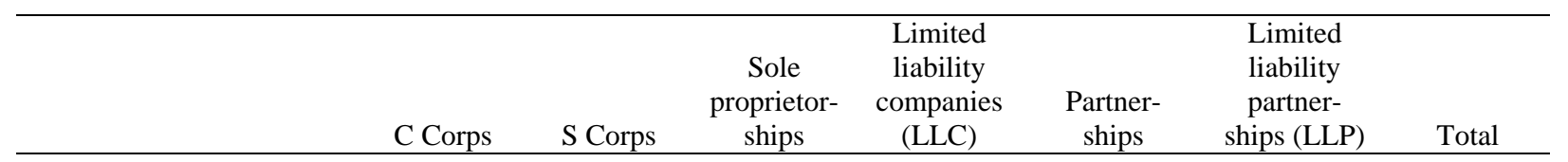

\section{Panel A: All firms}

No. of firms

904,249

$1,953,452 \quad 2,675,680$

345,639

$343,479 \quad 75,605$

$6,298,104$

No. of shareholders

no more than

\begin{tabular}{|c|c|c|c|c|c|c|c|}
\hline 1 & 0.398 & 0.483 & 0.808 & 0.403 & 0.022 & 0.160 & 0.575 \\
\hline 2 & 0.735 & 0.851 & 1.000 & 0.828 & 0.699 & 0.758 & 0.887 \\
\hline 3 & 0.861 & 0.926 & 1.000 & 0.930 & 0.834 & 0.860 & 0.943 \\
\hline 4 & 0.901 & 0.969 & 1.000 & 0.971 & 0.927 & 0.909 & 0.970 \\
\hline 5 & 0.912 & 0.980 & 1.000 & 0.982 & 0.929 & 0.914 & 0.975 \\
\hline 6 & 0.933 & 0.988 & 1.000 & 0.989 & 0.936 & 0.970 & 0.982 \\
\hline 7 & 0.944 & 0.991 & 1.000 & 0.989 & 0.974 & 0.970 & 0.987 \\
\hline 8 & 0.951 & 0.992 & 1.000 & 0.990 & 0.975 & 0.970 & 0.988 \\
\hline 9 & 0.954 & 0.993 & 1.000 & 0.990 & 0.976 & 0.970 & 0.989 \\
\hline \multicolumn{8}{|c|}{ managed? } \\
\hline No & 0.103 & 0.070 & 0.026 & 0.060 & 0.077 & 0.204 & 0.058 \\
\hline Yes & 0.897 & 0.930 & 0.974 & 0.940 & 0.923 & 0.796 & 0.942 \\
\hline
\end{tabular}

\section{Panel B: Larger firms (20-499 employees)}

No. of firms

No. of shareholders

no more than

1
2
3
4
5
6
7
8
9

Owner managed?

\begin{tabular}{|c|c|c|c|c|c|c|c|}
\hline 1 & 0.234 & 0.363 & 0.700 & 0.158 & 0.052 & 0.229 & 0.309 \\
\hline 2 & 0.552 & 0.686 & 1.000 & 0.676 & 0.562 & 0.620 & 0.648 \\
\hline 3 & 0.712 & 0.807 & 1.000 & 0.772 & 0.704 & 0.655 & 0.774 \\
\hline 4 & 0.793 & 0.887 & 1.000 & 0.844 & 0.759 & 0.814 & 0.851 \\
\hline 5 & 0.819 & 0.930 & 1.000 & 0.922 & 0.784 & 0.839 & 0.886 \\
\hline 6 & 0.870 & 0.954 & 1.000 & 0.930 & 0.790 & 0.839 & 0.916 \\
\hline 7 & 0.878 & 0.969 & 1.000 & 0.930 & 0.826 & 0.839 & 0.927 \\
\hline 8 & 0.898 & 0.974 & 1.000 & 0.930 & 0.832 & 0.839 & 0.937 \\
\hline 9 & 0.903 & 0.977 & 1.000 & 0.930 & 0.843 & 0.839 & 0.941 \\
\hline \multicolumn{8}{|c|}{ managed? } \\
\hline No & 0.165 & 0.158 & 0.224 & 0.327 & 0.131 & 0.081 & 0.168 \\
\hline Yes & 0.835 & 0.842 & 0.776 & 0.673 & 0.869 & 0.919 & 0.832 \\
\hline
\end{tabular}




\section{Table A9. Firm Characteristics.}

This table (which appears in more extensive form as Table 1 in Asker, Farre-Mensa, and Ljungqvist (2010)) reports means and standard deviations (in italics underneath the means) for certain characteristics of the full samples of 3,926 Compustat and 32,204 Sageworks firms and the matched samples of 1,666 Compustat and 620 Sageworks unique firms used in Asker, Farre-Mensa, and Ljungqvist (2010). Total assets (Compustat item at or its Sageworks equivalent) is in \$ millions of 2000 purchasing power, deflated using the annual GDP deflator, at the beginning of the fiscal year. Gross investment is the annual increase in gross fixed assets (Compustat data item ppegt or its Sageworks equivalent) scaled by beginning-of-year nominal total assets; net investment is defined analogously using net fixed assets (Compustat item ppent or its Sageworks equivalent). Sales growth is the annual percentage increase in sales (Compustat item sale or its Sageworks equivalent). ROA is operating income before depreciation (Compustat item oibdp or its Sageworks equivalent) scaled by beginning-of-year total assets. Cash holdings is beginning-of-year cash and short-term investments (Compustat item che or its Sageworks equivalent) and book leverage is beginning-of-year long-term and short-term debt (Compustat items dltt + dlc or their Sageworks equivalents), both scaled by beginning-of-year total assets. All variables are winsorized $0.5 \%$ in each tail to reduce the impact of outliers. The unit of observation is a firm-year. The last four columns report pairwise differences in means or medians between the relevant samples, with ***, **, and * indicating a difference that is significant in a $t$-test for equality of means at the $1 \%$, $5 \%$, and $10 \%$ level, respectively.

\begin{tabular}{|c|c|c|c|c|c|c|c|c|}
\hline & \multicolumn{2}{|c|}{ Full sample (F) } & \multicolumn{2}{|c|}{ Matched sample (M) } & \multicolumn{4}{|c|}{ Differences in means ( $t$-test) } \\
\hline & Public & Private & Public & Private & F:Pub-Pri & M:Pub-Pri & Pub: $F-M$ & Pri: $F-M$ \\
\hline \multirow[t]{2}{*}{ Total real assets $(\$ \mathrm{~m})$} & $1,364.4$ & 7.1 & 144.7 & 120.0 & $1,357.3^{* * *}$ & $24.7^{*}$ & $1,219.7^{* * *}$ & $-112.9^{* * *}$ \\
\hline & 2,958.1 & 190.2 & 692.8 & 675.5 & & & & \\
\hline \multirow[t]{2}{*}{ Gross investment } & 0.045 & 0.076 & 0.040 & 0.097 & $-0.031^{* * *}$ & $-0.056^{* * *}$ & $0.005^{*}$ & $-0.020^{* * *}$ \\
\hline & 0.154 & 0.261 & 0.191 & 0.304 & & & & \\
\hline \multirow[t]{2}{*}{ Net investment } & 0.022 & 0.033 & 0.022 & 0.094 & $-0.011^{* * *}$ & $-0.072^{* * *}$ & 0.000 & $-0.061^{* * *}$ \\
\hline & 0.123 & 0.205 & 0.150 & 0.302 & & & & \\
\hline \multirow[t]{2}{*}{ Sales growth } & 0.183 & 0.177 & 0.256 & 0.327 & 0.006 & $-0.071^{* * *}$ & $-0.073^{* * *}$ & $-0.150^{* * *}$ \\
\hline & 0.674 & 0.652 & 0.925 & 1.075 & & & & \\
\hline \multirow[t]{2}{*}{ ROA } & 0.065 & 0.075 & -0.060 & 0.084 & $-0.010^{* *}$ & $-0.144^{* * *}$ & $0.124^{* * *}$ & -0.009 \\
\hline & 0.286 & 1.069 & 0.437 & 0.986 & & & & \\
\hline \multirow[t]{2}{*}{ Cash holdings } & 0.225 & 0.152 & 0.304 & 0.151 & $0.073^{* * *}$ & $0.152^{* * *}$ & $-0.078^{* * *}$ & 0.001 \\
\hline & 0.239 & 0.202 & 0.267 & 0.200 & & & & \\
\hline \multirow[t]{2}{*}{ Book leverage } & 0.199 & 0.311 & 0.149 & 0.218 & $-0.111^{* * *}$ & $-0.069^{* * *}$ & $0.050^{* * *}$ & $0.092^{* * *}$ \\
\hline & 0.230 & 0.455 & 0.250 & 0.264 & & & & \\
\hline No. of observations & 19,203 & 88,568 & 4,975 & 4,975 & & & & \\
\hline No. of firms & 3,926 & 32,204 & 1,666 & 620 & & & & \\
\hline
\end{tabular}


Table A10. Number of Firm-years, Total Real Assets, and Sales Growth by Fiscal Year.

The unit of observation in this table is a firm-year. For details of the sample construction and variable definitions, see Tables A2 and A9, respectively.

\begin{tabular}{|c|c|c|c|c|c|c|c|c|c|c|c|c|}
\hline & \multicolumn{4}{|c|}{ Number of firm-years } & \multicolumn{4}{|c|}{ Mean total real assets (\$m) } & \multicolumn{4}{|c|}{ Mean sales growth } \\
\hline & \multicolumn{2}{|c|}{ Full sample (F) } & \multicolumn{2}{|c|}{$\begin{array}{l}\text { Matched sample } \\
\text { (M) }\end{array}$} & \multicolumn{2}{|c|}{ Full sample (F) } & \multicolumn{2}{|c|}{$\begin{array}{l}\text { Matched sample } \\
\text { (M) }\end{array}$} & \multicolumn{2}{|c|}{ Full sample (F) } & \multicolumn{2}{|c|}{$\begin{array}{l}\text { Matched sample } \\
\text { (M) }\end{array}$} \\
\hline & Public & Private & Public & Private & Public & Private & Public & Private & Public & Private & Public & Private \\
\hline 2002 & 3,352 & 2,535 & 311 & 311 & $1,255.9$ & 3.3 & 54.1 & 37.9 & 0.097 & 0.129 & 0.077 & 0.090 \\
\hline 2003 & 3,426 & 6,069 & 555 & 555 & $1,245.1$ & 3.0 & 49.4 & 37.9 & 0.157 & 0.155 & 0.215 & 0.220 \\
\hline 2004 & 3,293 & 13,147 & 910 & 910 & $1,327.3$ & 4.7 & 94.5 & 74.9 & 0.221 & 0.207 & 0.260 & 0.261 \\
\hline 2005 & 3,219 & 21,611 & 1,060 & 1,060 & $1,365.9$ & 6.0 & 164.1 & 136.8 & 0.240 & 0.203 & 0.318 & 0.243 \\
\hline 2006 & 3,134 & 26,267 & 1,166 & 1,166 & $1,434.7$ & 8.0 & 180.1 & 153.0 & 0.207 & 0.203 & 0.261 & 0.741 \\
\hline 2007 & 2,779 & 18,939 & 973 & 973 & $1,604.9$ & 10.5 & 211.3 & 177.3 & 0.179 & 0.104 & 0.258 & 0.121 \\
\hline
\end{tabular}


Table A11. Number of Firm-years, Total Real Assets, and Sales Growth by Industry.

The unit of observation in this table is a firm-year. For details of the sample construction and variable definitions, see Tables A2 and A9, respectively.

\begin{tabular}{|c|c|c|c|c|c|c|c|c|c|c|c|c|}
\hline & \multicolumn{4}{|c|}{ Number of firm-years } & \multicolumn{4}{|c|}{ Mean total real assets (\$m) } & \multicolumn{4}{|c|}{ Mean sales growth } \\
\hline & \multicolumn{2}{|c|}{ Full sample (F) } & \multicolumn{2}{|c|}{$\begin{array}{l}\text { Matched sample } \\
\text { (M) }\end{array}$} & \multicolumn{2}{|c|}{ Full sample (F) } & \multicolumn{2}{|c|}{$\begin{array}{l}\text { Matched sample } \\
\text { (M) }\end{array}$} & \multicolumn{2}{|c|}{ Full sample (F) } & \multicolumn{2}{|c|}{$\begin{array}{l}\text { Matched sample } \\
\text { (M) }\end{array}$} \\
\hline & Public & Private & Public & Private & Public & Private & Public & Private & Public & Private & Public & Private \\
\hline Food products & 447 & 2,562 & 127 & 83 & $2,491.7$ & 5.9 & 155.4 & 73.1 & 0.097 & 0.183 & 0.134 & 0.229 \\
\hline Beer \& liquor & 74 & 171 & 22 & 29 & $4,497.6$ & 7.7 & 41.9 & 53.8 & 0.087 & 0.263 & 0.132 & 0.157 \\
\hline Tobacco products & 30 & 4 & 0 & 0 & $5,743.2$ & 1.8 & & & -0.083 & 2.348 & & \\
\hline Recreation & 469 & 2,788 & 111 & 100 & $1,140.7$ & 14.9 & 111.6 & 67.1 & 0.164 & 0.164 & 0.150 & 0.176 \\
\hline Printing \& publishing & 255 & 834 & 47 & 42 & $1,831.6$ & 7.0 & 306.6 & 309.3 & 0.061 & 0.110 & 0.136 & 0.732 \\
\hline Consumer goods & 313 & 841 & 53 & 148 & $1,651.7$ & 5.4 & 58.5 & 44.5 & 0.099 & 0.198 & -0.008 & 0.087 \\
\hline Apparel & 334 & 82 & 71 & 38 & 710.6 & 10.3 & 69.5 & 73.5 & 0.118 & 0.150 & 0.099 & 0.175 \\
\hline Healthcare, medical equipment, pharma. prods. & 2,783 & 4,045 & 1,004 & 801 & 778.0 & 10.4 & 50.4 & 42.8 & 0.389 & 0.170 & 0.465 & 0.779 \\
\hline Chemicals & 418 & 422 & 75 & 79 & $2,166.1$ & 6.9 & 40.3 & 69.9 & 0.124 & 0.193 & 0.257 & 0.539 \\
\hline Textiles & 64 & 105 & 1 & 5 & 850.2 & 9.4 & 16.5 & 29.8 & -0.011 & 0.121 & -0.133 & 0.071 \\
\hline Construction and construction materials & 594 & 8,347 & 113 & 101 & $1,477.2$ & 10.0 & 145.2 & 106.3 & 0.106 & 0.185 & 0.085 & 0.062 \\
\hline Steel works Etc & 254 & 629 & 22 & 7 & $1,553.8$ & 9.1 & 50.6 & 107.5 & 0.221 & 0.231 & 0.126 & 0.542 \\
\hline Fabricated products and machinery & 823 & 2,441 & 154 & 119 & $1,086.7$ & 4.2 & 41.4 & 27.4 & 0.125 & 0.160 & 0.237 & 0.191 \\
\hline Electrical equipment & 387 & 709 & 132 & 82 & 695.5 & 4.9 & 35.1 & 28.2 & 0.156 & 0.161 & 0.262 & 0.086 \\
\hline Automobiles and trucks & 292 & 308 & 31 & 34 & $2,573.1$ & 7.4 & 80.6 & 45.8 & 0.117 & 0.190 & 0.345 & 0.133 \\
\hline Aircraft, ships, and railorad equipment & 168 & 200 & 24 & 17 & $3,275.4$ & 4.6 & 47.9 & 15.4 & 0.105 & 0.215 & 0.050 & 0.240 \\
\hline Precious metal, non-metallic, ind. metal mining & 92 & 149 & 1 & 3 & $1,762.6$ & 5.1 & 87.2 & 18.1 & 0.172 & 0.102 & -0.095 & 0.262 \\
\hline Coal & 53 & 30 & 2 & 2 & $2,299.4$ & 7.2 & 76.8 & 54.9 & 0.380 & 0.144 & 0.194 & -0.112 \\
\hline Petroleum and natural gas & 777 & 359 & 242 & 203 & $2,321.7$ & 6.7 & 140.5 & 95.1 & 0.369 & 0.384 & 0.581 & 0.349 \\
\hline Communication & 663 & 590 & 84 & 102 & $3,294.2$ & 16.2 & 94.4 & 78.1 & 0.182 & 0.203 & 0.270 & 0.673 \\
\hline Personal and business services & 3,186 & 33,556 & 795 & 1,027 & 798.9 & 4.1 & 151.0 & 105.1 & 0.159 & 0.212 & 0.225 & 0.249 \\
\hline Business equipment & 3,105 & 678 & 1,230 & 1,287 & 920.1 & 61.1 & 166.6 & 132.4 & 0.149 & 0.205 & 0.176 & 0.261 \\
\hline Business supplies and shipping containers & 307 & 417 & 33 & 34 & $3,189.3$ & 8.8 & 64.1 & 37.4 & 0.058 & 0.146 & 0.046 & 0.074 \\
\hline Transportation & 532 & 2,631 & 55 & 58 & $2,276.6$ & 4.0 & 160.0 & 115.7 & 0.152 & 0.176 & 0.188 & 0.142 \\
\hline Wholesale & 790 & 9,007 & 222 & 217 & $1,074.4$ & 10.2 & 259.1 & 242.1 & 0.133 & 0.145 & 0.141 & 0.106 \\
\hline Retail & 1,207 & 10,720 & 110 & 147 & $1,950.9$ & 7.7 & 865.4 & 693.4 & 0.106 & 0.110 & 0.127 & 0.080 \\
\hline Restaurants, hotels, motels & 421 & 3,158 & 117 & 128 & 993.0 & 4.6 & 326.7 & 233.2 & 0.112 & 0.125 & 0.083 & 0.284 \\
\hline Everything else & 365 & 2,785 & 97 & 82 & $1,304.4$ & 4.2 & 95.4 & 40.0 & 0.104 & 0.153 & 0.166 & 0.076 \\
\hline
\end{tabular}


Table A12. Number of Firm-years, Total Real Assets, and Sales Growth by State.

The unit of observation in this table is a firm-year. For details of the sample construction and variable definitions, see Tables A2 and A9, respectively.

\begin{tabular}{|c|c|c|c|c|c|c|c|c|c|c|c|c|}
\hline & \multicolumn{4}{|c|}{ Number of firm-years } & \multicolumn{4}{|c|}{ Mean total real assets (\$m) } & \multicolumn{4}{|c|}{ Mean sales growth } \\
\hline & \multicolumn{2}{|c|}{ Full sample (F) } & \multicolumn{2}{|c|}{$\begin{array}{l}\text { Matched sample } \\
\text { (M) }\end{array}$} & \multicolumn{2}{|c|}{ Full sample (F) } & \multicolumn{2}{|c|}{$\begin{array}{l}\text { Matched sample } \\
\text { (M) }\end{array}$} & \multicolumn{2}{|c|}{ Full sample (F) } & \multicolumn{2}{|c|}{$\begin{array}{l}\text { Matched sample } \\
\text { (M) }\end{array}$} \\
\hline & Public & Private & Public & Private & Public & Private & Public & Private & Public & Private & Public & Private \\
\hline $\mathrm{AK}$ & 12 & 227 & 0 & 0 & 687.4 & 2.4 & & & 0.046 & 0.235 & & \\
\hline $\mathrm{AL}$ & 87 & 1,395 & 23 & 26 & 609.2 & 3.5 & 174.6 & 21.7 & 0.224 & 0.177 & 0.652 & 0.159 \\
\hline AR & 86 & 971 & 14 & 2 & $3,516.1$ & 2.7 & 160.5 & 1.6 & 0.112 & 0.184 & 0.147 & 0.269 \\
\hline $\mathrm{AZ}$ & 305 & 1,315 & 82 & 152 & $1,079.7$ & 3.0 & 249.6 & 17.8 & 0.163 & 0.238 & 0.217 & 0.103 \\
\hline CA & 3,674 & 5,997 & 1,127 & 722 & 918.8 & 5.1 & 148.3 & 42.6 & 0.230 & 0.178 & 0.311 & 0.864 \\
\hline $\mathrm{CO}$ & 435 & 2,286 & 133 & 112 & $1,309.9$ & 2.9 & 68.0 & 30.5 & 0.279 & 0.253 & 0.320 & 0.449 \\
\hline $\mathrm{CT}$ & 455 & 1,200 & 87 & 105 & $1,266.6$ & 3.5 & 83.8 & 122.8 & 0.142 & 0.135 & 0.115 & 0.435 \\
\hline DC & 40 & 85 & 0 & 0 & $2,245.1$ & 4.1 & & & 0.547 & 0.172 & & \\
\hline $\mathrm{DE}$ & 55 & 265 & 14 & 17 & $2,063.8$ & 5.4 & 48.9 & 22.3 & 0.029 & 0.208 & 0.061 & 1.028 \\
\hline FL & 852 & 3,589 & 249 & 236 & 774.8 & 11.0 & 68.7 & 24.3 & 0.131 & 0.209 & 0.206 & 0.084 \\
\hline GA & 547 & 2,499 & 136 & 443 & $1,529.4$ & 16.2 & 449.9 & 68.7 & 0.101 & 0.261 & 0.110 & 0.354 \\
\hline HI & 30 & 419 & 16 & 4 & 447.1 & 3.4 & 80.8 & 33.3 & 0.026 & 0.135 & -0.047 & 0.197 \\
\hline IA & 88 & 1,261 & 18 & 17 & 968.7 & 3.8 & 177.5 & 18.0 & 0.078 & 0.145 & 0.104 & 0.060 \\
\hline ID & 46 & 605 & 6 & 3 & $2,485.6$ & 3.9 & 86.6 & 5.5 & 0.334 & 0.213 & 1.654 & 0.082 \\
\hline IL & 780 & 3,209 & 149 & 149 & $2,407.1$ & 4.2 & 116.4 & 41.9 & 0.115 & 0.128 & 0.247 & 0.109 \\
\hline IN & 201 & 3,003 & 33 & 25 & $1,260.2$ & 2.7 & 83.3 & 40.7 & 0.085 & 0.132 & 0.124 & 0.058 \\
\hline KS & 98 & 1,220 & 21 & 26 & $1,336.4$ & 25.7 & 103.2 & 60.6 & 0.185 & 0.157 & 0.375 & 0.265 \\
\hline $\mathrm{KY}$ & 113 & 1,176 & 11 & 61 & $1,458.4$ & 4.8 & 950.2 & 82.3 & 0.093 & 0.152 & 0.010 & 0.131 \\
\hline LA & 114 & 804 & 19 & 40 & $1,205.9$ & 4.6 & 166.3 & 30.8 & 0.216 & 0.208 & 0.433 & 0.177 \\
\hline MA & 1,099 & 2,770 & 346 & 95 & 712.1 & 3.2 & 86.5 & 36.6 & 0.247 & 0.127 & 0.238 & 0.105 \\
\hline MD & 298 & 1,665 & 95 & 63 & $1,079.3$ & 3.4 & 114.7 & 15.9 & 0.269 & 0.209 & 0.323 & 0.305 \\
\hline $\mathrm{ME}$ & 24 & 413 & 10 & 0 & 617.2 & 2.6 & 11.2 & & 0.073 & 0.112 & 0.113 & \\
\hline MI & 358 & 3,841 & 64 & 109 & $2,436.0$ & 3.3 & 79.2 & 71.8 & 0.116 & 0.108 & 0.254 & 0.064 \\
\hline MN & 676 & 3,461 & 238 & 132 & 1,149.6 & 28.9 & 93.2 & 110.3 & 0.135 & 0.131 & 0.112 & 0.262 \\
\hline MO & 293 & 1,823 & 31 & 190 & $2,162.5$ & 5.5 & 116.1 & 360.2 & 0.112 & 0.171 & 0.082 & 0.098 \\
\hline MS & 36 & 923 & 4 & 2 & 510.0 & 3.1 & 232.7 & 100.0 & 0.126 & 0.186 & 0.385 & 0.197 \\
\hline $\mathrm{MT}$ & 15 & 621 & 0 & 0 & 380.6 & 1.3 & & & 0.128 & 0.198 & & \\
\hline NC & 309 & 2,723 & 67 & 141 & $1,544.1$ & 19.9 & 809.7 & 678.1 & 0.191 & 0.199 & 0.275 & 0.548 \\
\hline
\end{tabular}


Table A12. Continued.

\begin{tabular}{|c|c|c|c|c|c|c|c|c|c|c|c|c|}
\hline & \multicolumn{4}{|c|}{ Number of firm-years } & \multicolumn{4}{|c|}{ Mean total real assets (\$m) } & \multicolumn{4}{|c|}{ Mean sales growth } \\
\hline & \multicolumn{2}{|c|}{ Full sample (F) } & \multicolumn{2}{|c|}{$\begin{array}{l}\text { Matched sample } \\
\text { (M) }\end{array}$} & \multicolumn{2}{|c|}{ Full sample (F) } & \multicolumn{2}{|c|}{$\begin{array}{l}\text { Matched sample } \\
\text { (M) }\end{array}$} & \multicolumn{2}{|c|}{ Full sample (F) } & \multicolumn{2}{|c|}{$\begin{array}{l}\text { Matched sample } \\
\text { (M) }\end{array}$} \\
\hline & Public & Private & Public & Private & Public & Private & Public & Private & Public & Private & Public & Private \\
\hline ND & 5 & 206 & 4 & 0 & 10.4 & 1.6 & 11.0 & & 0.183 & 0.204 & 0.237 & \\
\hline $\mathrm{NE}$ & 74 & 904 & 18 & 100 & $2,437.3$ & 4.0 & 67.5 & 23.3 & 0.071 & 0.137 & 0.036 & 0.126 \\
\hline $\mathrm{NH}$ & 77 & 1,039 & 22 & 55 & 388.7 & 2.7 & 56.5 & 10.6 & 0.144 & 0.113 & 0.149 & 0.076 \\
\hline $\mathrm{NJ}$ & 843 & 2,996 & 257 & 129 & $1,439.3$ & 5.4 & 101.6 & 54.2 & 0.210 & 0.143 & 0.302 & 0.116 \\
\hline NM & 10 & 311 & 3 & 2 & 202.9 & 2.8 & 124.7 & 7.2 & 0.017 & 0.216 & 0.090 & -0.010 \\
\hline NV & 140 & 540 & 49 & 156 & $2,024.2$ & 5.4 & 72.6 & 58.2 & 0.230 & 0.354 & 0.282 & 0.469 \\
\hline NY & 1,459 & 3,132 & 430 & 268 & $1,668.8$ & 16.6 & 185.9 & 442.1 & 0.186 & 0.159 & 0.270 & 0.265 \\
\hline $\mathrm{OH}$ & 608 & 5,188 & 72 & 203 & $1,884.5$ & 3.9 & 212.6 & 71.0 & 0.081 & 0.142 & 0.068 & 0.083 \\
\hline OK & 129 & 613 & 46 & 54 & $1,768.2$ & 4.0 & 64.7 & 79.8 & 0.245 & 0.252 & 0.393 & 0.565 \\
\hline OR & 227 & 912 & 59 & 100 & 629.5 & 6.7 & 77.3 & 110.2 & 0.209 & 0.162 & 0.392 & 0.123 \\
\hline PA & 821 & 5,833 & 158 & 462 & $1,362.7$ & 5.0 & 161.9 & 35.8 & 0.206 & 0.148 & 0.324 & 0.263 \\
\hline RI & 57 & 315 & 19 & 6 & 3,342.9 & 3.9 & 49.9 & 16.8 & 0.091 & 0.154 & 0.118 & 0.069 \\
\hline SC & 73 & 1,116 & 7 & 12 & 688.4 & 2.3 & 37.1 & 51.2 & 0.079 & 0.214 & 0.143 & 0.115 \\
\hline SD & 18 & 499 & 9 & 0 & 160.4 & 2.2 & 123.5 & & 0.171 & 0.184 & 0.190 & \\
\hline $\mathrm{TN}$ & 306 & 1,610 & 30 & 28 & $1,710.2$ & 4.5 & 256.8 & 236.0 & 0.145 & 0.178 & 0.100 & 0.049 \\
\hline TX & 1,746 & 4,828 & 405 & 258 & $1,903.6$ & 6.4 & 110.8 & 119.6 & 0.196 & 0.266 & 0.292 & 0.276 \\
\hline UT & 137 & 1,268 & 60 & 77 & 324.0 & 5.0 & 67.6 & 175.3 & 0.198 & 0.303 & 0.206 & 0.400 \\
\hline VA & 484 & 1,825 & 109 & 60 & $1,470.6$ & 8.8 & 152.8 & 658.4 & 0.140 & 0.186 & 0.203 & 0.118 \\
\hline VT & 30 & 292 & 11 & 3 & 233.8 & 1.7 & 53.3 & 3.1 & 0.083 & 0.193 & 0.159 & -0.004 \\
\hline WA & 405 & 2,240 & 111 & 39 & $1,276.5$ & 5.2 & 164.6 & 666.3 & 0.224 & 0.242 & 0.268 & 0.144 \\
\hline WI & 276 & 2,370 & 33 & 78 & $1,337.4$ & 3.8 & 79.6 & 27.2 & 0.123 & 0.137 & 0.201 & 0.087 \\
\hline WV & 23 & 354 & 8 & 11 & 381.1 & 4.6 & 153.2 & 24.4 & 0.117 & 0.165 & 0.127 & 0.158 \\
\hline WY & 6 & 411 & 4 & 2 & 27.0 & 1.8 & 36.3 & 6.4 & 0.520 & 0.258 & 0.385 & 0.298 \\
\hline Other & 123 & & 58 & & 622.9 & & 55.7 & & 0.146 & & 0.158 & \\
\hline
\end{tabular}


Table A13. Number of Firm-years, Total Real Assets, and Sales Growth by Legal Form of Organization.

The unit of observation in this table is a firm-year. For details of the sample construction and variable definitions, see Tables A2 and A9, respectively.

\begin{tabular}{|c|c|c|c|c|c|c|c|c|c|c|c|c|}
\hline & \multicolumn{4}{|c|}{ Number of firm-years } & \multicolumn{4}{|c|}{ Mean total real assets (\$m) } & \multicolumn{4}{|c|}{ Mean sales growth } \\
\hline & \multicolumn{2}{|c|}{ Full sample (F) } & \multicolumn{2}{|c|}{$\begin{array}{l}\text { Matched sample } \\
\text { (M) }\end{array}$} & \multicolumn{2}{|c|}{ Full sample (F) } & \multicolumn{2}{|c|}{$\begin{array}{l}\text { Matched sample } \\
\text { (M) }\end{array}$} & \multicolumn{2}{|c|}{ Full sample (F) } & \multicolumn{2}{|c|}{$\begin{array}{l}\text { Matched sample } \\
\text { (M) }\end{array}$} \\
\hline & Public & Private & Public & Private & Public & Private & Public & Private & Public & Private & Public & Private \\
\hline C Corps & 19,191 & 33,072 & 4,972 & 3,024 & $1,364.1$ & 12.9 & 144.6 & 174.8 & 0.182 & 0.147 & 0.255 & 0.456 \\
\hline S Corps & & 43,621 & & 1,513 & & 3.4 & & 28.3 & & 0.175 & & 0.107 \\
\hline Sole proprietorships & & 1,321 & & 13 & & 1.1 & & 113.6 & & 0.170 & & 0.048 \\
\hline Limited liability companies (LLC) & & 5,734 & & 252 & & 4.2 & & 41.2 & & 0.338 & & 0.223 \\
\hline Partnerships & 12 & 2,490 & 3 & 49 & $1,776.2$ & 4.1 & 253.3 & 39.9 & 0.925 & 0.284 & 1.901 & 0.356 \\
\hline Limited liability partnerships (LLP) & & 478 & & 39 & & 6.7 & & 42.8 & & 0.142 & & 0.116 \\
\hline Other & & 1,852 & & 85 & & 6.2 & & 118.6 & & 0.143 & & 0.059 \\
\hline
\end{tabular}


Table A14. Number of Firm-years, Gross Investment, and Net Investment by Fiscal Year.

The unit of observation in this table is a firm-year. For details of the sample construction and variable definitions, see Tables A2 and A9, respectively.

\begin{tabular}{|c|c|c|c|c|c|c|c|c|c|c|c|c|}
\hline & \multicolumn{4}{|c|}{ Number of firm-years } & \multicolumn{4}{|c|}{ Mean gross investment } & \multicolumn{4}{|c|}{ Mean net investment } \\
\hline & \multicolumn{2}{|c|}{ Full sample (F) } & \multicolumn{2}{|c|}{$\begin{array}{l}\text { Matched sample } \\
\text { (M) }\end{array}$} & \multicolumn{2}{|c|}{ Full sample (F) } & \multicolumn{2}{|c|}{$\begin{array}{l}\text { Matched sample } \\
\text { (M) }\end{array}$} & \multicolumn{2}{|c|}{ Full sample (F) } & \multicolumn{2}{|c|}{$\begin{array}{l}\text { Matched sample } \\
\text { (M) }\end{array}$} \\
\hline & Public & Private & Public & Private & Public & Private & Public & Private & Public & Private & Public & Private \\
\hline 2002 & 3,352 & 2,535 & 311 & 311 & 0.035 & 0.058 & 0.008 & 0.058 & 0.008 & 0.019 & -0.005 & 0.036 \\
\hline 2003 & 3,426 & 6,069 & 555 & 555 & 0.036 & 0.067 & 0.021 & 0.138 & 0.009 & 0.025 & 0.002 & 0.111 \\
\hline 2004 & 3,293 & 13,147 & 910 & 910 & 0.045 & 0.075 & 0.038 & 0.160 & 0.022 & 0.028 & 0.020 & 0.106 \\
\hline 2005 & 3,219 & 21,611 & 1,060 & 1,060 & 0.043 & 0.083 & 0.040 & 0.068 & 0.025 & 0.040 & 0.024 & 0.056 \\
\hline 2006 & 3,134 & 26,267 & 1,166 & 1,166 & 0.058 & 0.083 & 0.048 & 0.090 & 0.036 & 0.037 & 0.030 & 0.155 \\
\hline 2007 & 2,779 & 18,939 & 973 & 973 & 0.059 & 0.066 & 0.054 & 0.066 & 0.037 & 0.027 & 0.034 & 0.060 \\
\hline
\end{tabular}


Table A15. Number of Firm-years, Gross Investment, and Net Investment by Industry.

The unit of observation in this table is a firm-year. For details of the sample construction and variable definitions, see Tables A2 and A9, respectively.

\begin{tabular}{|c|c|c|c|c|c|c|c|c|c|c|c|c|}
\hline & \multicolumn{4}{|c|}{ Number of firm-years } & \multicolumn{4}{|c|}{ Mean gross investment } & \multicolumn{4}{|c|}{ Mean net investment } \\
\hline & \multicolumn{2}{|c|}{ Full sample (F) } & \multicolumn{2}{|c|}{$\begin{array}{l}\text { Matched sample } \\
\text { (M) }\end{array}$} & \multicolumn{2}{|c|}{ Full sample (F) } & \multicolumn{2}{|c|}{$\begin{array}{l}\text { Matched sample } \\
\text { (M) }\end{array}$} & \multicolumn{2}{|c|}{ Full sample (F) } & \multicolumn{2}{|c|}{$\begin{array}{l}\text { Matched sample } \\
\text { (M) }\end{array}$} \\
\hline & Public & Private & Public & Private & Public & Private & Public & Private & Public & Private & Public & Private \\
\hline Food products & 447 & 2,562 & 127 & 83 & 0.040 & 0.110 & 0.039 & 0.067 & 0.016 & 0.045 & 0.019 & 0.030 \\
\hline Beer \& liquor & 74 & 171 & 22 & 29 & 0.043 & 0.101 & 0.039 & 0.032 & 0.013 & 0.051 & -0.001 & 0.028 \\
\hline Tobacco products & 30 & 4 & 0 & 0 & -0.010 & 0.288 & & & -0.011 & 0.141 & & \\
\hline Recreation & 469 & 2,788 & 111 & 100 & 0.073 & 0.092 & 0.064 & 0.059 & 0.042 & 0.036 & 0.034 & 0.038 \\
\hline Printing \& publishing & 255 & 834 & 47 & 42 & 0.030 & 0.064 & 0.045 & 0.134 & 0.011 & 0.033 & 0.023 & 0.112 \\
\hline Consumer goods & 313 & 841 & 53 & 148 & 0.024 & 0.043 & 0.013 & 0.041 & 0.009 & 0.013 & 0.012 & 0.040 \\
\hline Apparel & 334 & 82 & 71 & 38 & 0.024 & 0.027 & 0.014 & 0.020 & 0.009 & 0.011 & 0.002 & 0.004 \\
\hline Healthcare, medical equipment, pharma. prods. & 2,783 & 4,045 & 1,004 & 801 & 0.035 & 0.132 & 0.022 & 0.178 & 0.016 & 0.043 & 0.007 & 0.288 \\
\hline Chemicals & 418 & 422 & 75 & 79 & 0.044 & 0.064 & 0.053 & 0.411 & 0.018 & 0.026 & 0.034 & 0.366 \\
\hline Textiles & 64 & 105 & 1 & 5 & -0.033 & 0.036 & 0.002 & 0.144 & -0.016 & -0.004 & -0.005 & -0.007 \\
\hline Construction and construction materials & 594 & 8,347 & 113 & 101 & 0.029 & 0.077 & 0.034 & 0.029 & 0.011 & 0.033 & 0.014 & 0.019 \\
\hline Steel works Etc & 254 & 629 & 22 & 7 & 0.040 & 0.074 & 0.028 & 0.180 & 0.012 & 0.025 & 0.012 & -0.016 \\
\hline Fabricated products and machinery & 823 & 2,441 & 154 & 119 & 0.028 & 0.072 & 0.040 & 0.020 & 0.010 & 0.031 & 0.026 & 0.024 \\
\hline Electrical equipment & 387 & 709 & 132 & 82 & 0.029 & 0.039 & 0.038 & 0.021 & 0.016 & 0.013 & 0.032 & 0.014 \\
\hline Automobiles and trucks & 292 & 308 & 31 & 34 & 0.025 & 0.063 & 0.033 & -0.003 & 0.006 & 0.024 & 0.010 & -0.029 \\
\hline Aircraft, ships, and railorad equipment & 168 & 200 & 24 & 17 & 0.027 & 0.064 & 0.006 & 0.049 & 0.010 & 0.026 & -0.003 & -0.015 \\
\hline Precious metal, non-metallic, ind. metal mining & 92 & 149 & 1 & 3 & 0.151 & 0.180 & -0.026 & 0.628 & 0.099 & 0.093 & -0.034 & 0.481 \\
\hline Coal & 53 & 30 & 2 & 2 & 0.135 & 0.041 & 0.494 & 0.165 & 0.085 & -0.001 & 0.336 & -0.129 \\
\hline Petroleum and natural gas & 777 & 359 & 242 & 203 & 0.292 & 0.202 & 0.374 & 0.389 & 0.208 & 0.138 & 0.267 & 0.294 \\
\hline Communication & 663 & 590 & 84 & 102 & 0.044 & 0.102 & 0.043 & 0.254 & 0.003 & 0.048 & -0.003 & 0.186 \\
\hline Personal and business services & 3,186 & 33,556 & 795 & 1,027 & 0.025 & 0.084 & 0.014 & 0.047 & 0.008 & 0.037 & 0.005 & 0.032 \\
\hline Business equipment & 3,105 & 678 & 1,230 & 1,287 & 0.016 & 0.054 & 0.007 & 0.044 & 0.002 & 0.027 & 0.000 & 0.029 \\
\hline Business supplies and shipping containers & 307 & 417 & 33 & 34 & 0.028 & 0.067 & 0.013 & 0.041 & 0.001 & 0.030 & 0.000 & -0.016 \\
\hline Transportation & 532 & 2,631 & 55 & 58 & 0.077 & 0.130 & 0.059 & 0.056 & 0.056 & 0.065 & 0.049 & 0.035 \\
\hline Wholesale & 790 & 9,007 & 222 & 217 & 0.020 & 0.033 & 0.012 & 0.026 & 0.010 & 0.015 & 0.010 & 0.018 \\
\hline Retail & 1,207 & 10,720 & 110 & 147 & 0.064 & 0.046 & 0.039 & 0.036 & 0.031 & 0.021 & 0.017 & 0.016 \\
\hline Restaurants, hotels, motels & 421 & 3,158 & 117 & 128 & 0.101 & 0.086 & 0.093 & 0.273 & 0.054 & 0.031 & 0.042 & 0.203 \\
\hline Everything else & 365 & 2,785 & 97 & 82 & 0.041 & 0.068 & 0.048 & 0.112 & 0.010 & 0.030 & 0.023 & 0.008 \\
\hline
\end{tabular}


Table A16. Number of Firm-years, Gross Investment, and Net Investment by State.

The unit of observation in this table is a firm-year. For details of the sample construction and variable definitions, see Tables A2 and A9, respectively.

\begin{tabular}{|c|c|c|c|c|c|c|c|c|c|c|c|c|}
\hline & \multicolumn{4}{|c|}{ Number of firm-years } & \multicolumn{4}{|c|}{ Mean gross investment } & \multicolumn{4}{|c|}{ Mean net investment } \\
\hline & \multicolumn{2}{|c|}{ Full sample (F) } & \multicolumn{2}{|c|}{$\begin{array}{l}\text { Matched sample } \\
\text { (M) }\end{array}$} & \multicolumn{2}{|c|}{ Full sample (F) } & \multicolumn{2}{|c|}{$\begin{array}{l}\text { Matched sample } \\
\text { (M) }\end{array}$} & \multicolumn{2}{|c|}{ Full sample (F) } & \multicolumn{2}{|c|}{$\begin{array}{l}\text { Matched sample } \\
\text { (M) }\end{array}$} \\
\hline & Public & Private & Public & Private & Public & Private & Public & Private & Public & Private & Public & Private \\
\hline AK & 12 & 227 & 0 & 0 & 0.064 & 0.076 & & & 0.005 & 0.051 & & \\
\hline $\mathrm{AL}$ & 87 & 1,395 & 23 & 26 & 0.023 & 0.084 & -0.015 & 0.045 & 0.004 & 0.036 & -0.015 & 0.031 \\
\hline AR & 86 & 971 & 14 & 2 & 0.068 & 0.092 & 0.102 & 0.376 & 0.042 & 0.029 & 0.065 & 0.376 \\
\hline $\mathrm{AZ}$ & 305 & 1,315 & 82 & 152 & 0.065 & 0.088 & 0.041 & 0.070 & 0.038 & 0.045 & 0.025 & 0.010 \\
\hline CA & 3,674 & 5,997 & 1,127 & 722 & 0.027 & 0.059 & 0.013 & 0.003 & 0.010 & 0.027 & 0.004 & 0.163 \\
\hline $\mathrm{CO}$ & 435 & 2,286 & 133 & 112 & 0.122 & 0.094 & 0.133 & 0.285 & 0.076 & 0.039 & 0.084 & 0.197 \\
\hline CT & 455 & 1,200 & 87 & 105 & 0.042 & 0.069 & 0.079 & 0.062 & 0.016 & 0.023 & 0.047 & 0.057 \\
\hline DC & 40 & 85 & 0 & 0 & 0.055 & 0.086 & & & 0.002 & 0.063 & & \\
\hline $\mathrm{DE}$ & 55 & 265 & 14 & 17 & 0.004 & 0.047 & 0.037 & 0.144 & -0.009 & 0.020 & 0.024 & 0.100 \\
\hline FL & 852 & 3,589 & 249 & 236 & 0.036 & 0.091 & 0.027 & 0.028 & 0.015 & 0.045 & 0.008 & 0.006 \\
\hline GA & 547 & 2,499 & 136 & 443 & 0.024 & 0.084 & 0.018 & 0.089 & 0.005 & 0.040 & 0.004 & 0.064 \\
\hline $\mathrm{HI}$ & 30 & 419 & 16 & 4 & 0.097 & 0.060 & 0.097 & 0.105 & 0.067 & 0.041 & 0.077 & 0.077 \\
\hline IA & 88 & 1,261 & 18 & 17 & 0.034 & 0.086 & 0.107 & 0.037 & 0.014 & 0.038 & 0.089 & 0.017 \\
\hline ID & 46 & 605 & 6 & 3 & 0.158 & 0.104 & 0.241 & 0.152 & 0.095 & 0.052 & 0.187 & 0.001 \\
\hline IL & 780 & 3,209 & 149 & 149 & 0.029 & 0.062 & 0.009 & 0.034 & 0.008 & 0.024 & -0.005 & 0.030 \\
\hline IN & 201 & 3,003 & 33 & 25 & 0.047 & 0.064 & 0.013 & 0.004 & 0.023 & 0.023 & 0.006 & -0.010 \\
\hline KS & 98 & 1,220 & 21 & 26 & 0.071 & 0.061 & 0.041 & 0.044 & 0.042 & 0.024 & 0.028 & 0.023 \\
\hline KY & 113 & 1,176 & 11 & 61 & 0.041 & 0.068 & 0.070 & 0.090 & 0.016 & 0.027 & 0.020 & 0.057 \\
\hline LA & 114 & 804 & 19 & 40 & 0.154 & 0.102 & 0.363 & -0.072 & 0.091 & 0.044 & 0.233 & -0.077 \\
\hline MA & 1,099 & 2,770 & 346 & 95 & 0.024 & 0.065 & 0.016 & 0.029 & 0.007 & 0.024 & 0.007 & 0.013 \\
\hline MD & 298 & 1,665 & 95 & 63 & 0.033 & 0.070 & 0.030 & 0.100 & 0.016 & 0.037 & 0.015 & 0.081 \\
\hline ME & 24 & 413 & 10 & 0 & 0.034 & 0.064 & 0.026 & & 0.013 & 0.021 & 0.010 & \\
\hline MI & 358 & 3,841 & 64 & 109 & 0.030 & 0.059 & 0.035 & 0.042 & 0.011 & 0.022 & 0.019 & 0.023 \\
\hline MN & 676 & 3,461 & 238 & 132 & 0.035 & 0.082 & 0.029 & 0.142 & 0.014 & 0.031 & 0.014 & 0.119 \\
\hline MO & 293 & 1,823 & 31 & 190 & 0.055 & 0.082 & 0.023 & 0.063 & 0.029 & 0.039 & 0.007 & 0.055 \\
\hline MS & 36 & 923 & 4 & 2 & 0.097 & 0.097 & 0.141 & 0.021 & 0.052 & 0.037 & 0.052 & 0.021 \\
\hline MT & 15 & 621 & 0 & 0 & 0.020 & 0.106 & & & -0.010 & 0.033 & & \\
\hline $\mathrm{NC}$ & 309 & 2,723 & 67 & 141 & 0.042 & 0.076 & 0.040 & 0.033 & 0.015 & 0.031 & 0.015 & 0.020 \\
\hline
\end{tabular}


Table A16. Continued.

\begin{tabular}{|c|c|c|c|c|c|c|c|c|c|c|c|c|}
\hline & \multicolumn{4}{|c|}{ Number of firm-years } & \multicolumn{4}{|c|}{ Mean gross investment } & \multicolumn{4}{|c|}{ Mean net investment } \\
\hline & \multicolumn{2}{|c|}{ Full sample (F) } & \multicolumn{2}{|c|}{$\begin{array}{l}\text { Matched sample } \\
\text { (M) }\end{array}$} & \multicolumn{2}{|c|}{ Full sample (F) } & \multicolumn{2}{|c|}{$\begin{array}{l}\text { Matched sample } \\
\text { (M) }\end{array}$} & \multicolumn{2}{|c|}{ Full sample (F) } & \multicolumn{2}{|c|}{$\begin{array}{l}\text { Matched sample } \\
\text { (M) }\end{array}$} \\
\hline & Public & Private & Public & Private & Public & Private & Public & Private & Public & Private & Public & Private \\
\hline ND & 5 & 206 & 4 & 0 & 0.130 & 0.111 & 0.127 & & 0.118 & 0.045 & 0.133 & \\
\hline $\mathrm{NE}$ & 74 & 904 & 18 & 100 & 0.034 & 0.046 & 0.003 & 0.041 & 0.009 & 0.015 & -0.015 & 0.030 \\
\hline NH & 77 & 1,039 & 22 & 55 & 0.023 & 0.073 & -0.017 & 0.008 & 0.004 & 0.025 & -0.017 & -0.007 \\
\hline NJ & 843 & 2,996 & 257 & 129 & 0.028 & 0.059 & 0.016 & 0.081 & 0.009 & 0.022 & 0.001 & 0.041 \\
\hline NM & 10 & 311 & 3 & 2 & -0.011 & 0.112 & 0.010 & -0.046 & -0.033 & 0.060 & -0.010 & -0.046 \\
\hline NV & 140 & 540 & 49 & 156 & 0.122 & 0.127 & 0.087 & 0.037 & 0.089 & 0.069 & 0.043 & 0.034 \\
\hline NY & 1,459 & 3,132 & 430 & 268 & 0.028 & 0.062 & 0.027 & 0.035 & 0.012 & 0.027 & 0.012 & 0.033 \\
\hline $\mathrm{OH}$ & 608 & 5,188 & 72 & 203 & 0.026 & 0.066 & 0.009 & 0.053 & 0.008 & 0.025 & 0.000 & 0.050 \\
\hline OK & 129 & 613 & 46 & 54 & 0.194 & 0.079 & 0.277 & 0.592 & 0.138 & 0.042 & 0.215 & 0.515 \\
\hline OR & 227 & 912 & 59 & 100 & 0.024 & 0.075 & -0.002 & -0.030 & 0.004 & 0.037 & -0.013 & -0.036 \\
\hline $\mathrm{PA}$ & 821 & 5,833 & 158 & 462 & 0.047 & 0.073 & 0.036 & 0.359 & 0.022 & 0.029 & 0.023 & 0.288 \\
\hline RI & 57 & 315 & 19 & 6 & 0.030 & 0.087 & 0.026 & 0.061 & 0.016 & 0.043 & 0.013 & 0.059 \\
\hline SC & 73 & 1,116 & 7 & 12 & 0.016 & 0.101 & 0.026 & 0.037 & -0.003 & 0.033 & 0.022 & 0.018 \\
\hline SD & 18 & 499 & 9 & 0 & 0.127 & 0.114 & 0.108 & & 0.052 & 0.050 & 0.067 & \\
\hline $\mathrm{TN}$ & 306 & 1,610 & 30 & 28 & 0.072 & 0.070 & 0.075 & 0.047 & 0.044 & 0.034 & 0.046 & 0.027 \\
\hline $\mathrm{TX}$ & 1,746 & 4,828 & 405 & 258 & 0.102 & 0.089 & 0.129 & 0.254 & 0.066 & 0.050 & 0.092 & 0.156 \\
\hline UT & 137 & 1,268 & 60 & 77 & 0.055 & 0.103 & 0.029 & 0.042 & 0.035 & 0.048 & 0.022 & 0.030 \\
\hline VA & 484 & 1,825 & 109 & 60 & 0.032 & 0.106 & 0.020 & 0.078 & 0.012 & 0.051 & 0.010 & 0.047 \\
\hline VT & 30 & 292 & 11 & 3 & 0.068 & 0.101 & 0.037 & 0.018 & 0.028 & 0.040 & 0.003 & -0.046 \\
\hline WA & 405 & 2,240 & 111 & 39 & 0.045 & 0.098 & 0.033 & 0.071 & 0.023 & 0.042 & 0.019 & 0.059 \\
\hline WI & 276 & 2,370 & 33 & 78 & 0.026 & 0.066 & 0.027 & 0.050 & 0.009 & 0.031 & 0.013 & 0.039 \\
\hline WV & 23 & 354 & 8 & 11 & 0.189 & 0.083 & 0.133 & 0.031 & 0.131 & 0.048 & 0.081 & 0.075 \\
\hline WY & 6 & 411 & 4 & 2 & 0.620 & 0.135 & 0.454 & 0.894 & 0.446 & 0.053 & 0.348 & 0.708 \\
\hline Other & 123 & & 58 & & 0.072 & & 0.055 & & 0.033 & & 0.010 & \\
\hline
\end{tabular}


Table A17. Number of Firm-years, Gross Investment, and Net Investment by Legal Form of Organization.

The unit of observation in this table is a firm-year. For details of the sample construction and variable definitions, see Tables A2 and A9, respectively.

\begin{tabular}{|c|c|c|c|c|c|c|c|c|c|c|c|c|}
\hline & \multicolumn{4}{|c|}{ Number of firm-years } & \multicolumn{4}{|c|}{ Mean gross investment } & \multicolumn{4}{|c|}{ Mean net investment } \\
\hline & \multicolumn{2}{|c|}{ Full sample (F) } & \multicolumn{2}{|c|}{$\begin{array}{l}\text { Matched sample } \\
\text { (M) }\end{array}$} & \multicolumn{2}{|c|}{ Full sample (F) } & \multicolumn{2}{|c|}{$\begin{array}{l}\text { Matched sample } \\
\text { (M) }\end{array}$} & \multicolumn{2}{|c|}{ Full sample (F) } & \multicolumn{2}{|c|}{$\begin{array}{l}\text { Matched sample } \\
\text { (M) }\end{array}$} \\
\hline & Public & Private & Public & Private & Public & Private & Public & Private & Public & Private & Public & Private \\
\hline C Corps & 19,191 & 33,072 & 4,972 & 3,024 & 0.045 & 0.058 & 0.040 & 0.078 & 0.022 & 0.027 & 0.022 & 0.099 \\
\hline S Corps & & 43,621 & & 1,513 & & 0.084 & & 0.132 & & 0.035 & & 0.092 \\
\hline Sole proprietorships & & 1,321 & & 13 & & 0.121 & & 0.021 & & 0.058 & & -0.006 \\
\hline Limited liability companies (LLC) & & 5,734 & & 252 & & 0.107 & & 0.101 & & 0.050 & & 0.068 \\
\hline Partnerships & 12 & 2,490 & 3 & 49 & 0.315 & 0.097 & 0.319 & 0.136 & 0.269 & 0.034 & 0.244 & 0.084 \\
\hline Limited liability partnerships (LLP) & & 478 & & 39 & & 0.071 & & 0.047 & & 0.028 & & 0.023 \\
\hline Other & & 1,852 & & 85 & & 0.069 & & 0.116 & & 0.033 & & 0.091 \\
\hline
\end{tabular}


Table A18. ROA, Cash Holdings, and Leverage by Fiscal Year.

The unit of observation in this table is a firm-year. For details of the sample construction and variable definitions, see Tables A2 and A9, respectively.

\begin{tabular}{|c|c|c|c|c|c|c|c|c|c|c|c|c|}
\hline & \multicolumn{4}{|c|}{ Mean ROA } & \multicolumn{4}{|c|}{ Mean cash holdings } & \multicolumn{4}{|c|}{ Mean leverage } \\
\hline & \multicolumn{2}{|c|}{ Full sample (F) } & \multicolumn{2}{|c|}{$\begin{array}{l}\text { Matched sample } \\
\text { (M) }\end{array}$} & \multicolumn{2}{|c|}{ Full sample (F) } & \multicolumn{2}{|c|}{$\begin{array}{l}\text { Matched sample } \\
\text { (M) }\end{array}$} & \multicolumn{2}{|c|}{ Full sample (F) } & \multicolumn{2}{|c|}{$\begin{array}{l}\text { Matched sample } \\
\text { (M) }\end{array}$} \\
\hline & Public & Private & Public & Private & Public & Private & Public & Private & Public & Private & Public & Private \\
\hline 2002 & 0.052 & 0.191 & -0.079 & 0.143 & 0.213 & 0.149 & 0.241 & 0.106 & 0.215 & 0.216 & 0.203 & 0.214 \\
\hline 2003 & 0.059 & 0.126 & -0.106 & 0.209 & 0.215 & 0.152 & 0.265 & 0.128 & 0.212 & 0.233 & 0.185 & 0.219 \\
\hline 2004 & 0.072 & 0.129 & -0.060 & 0.202 & 0.229 & 0.154 & 0.304 & 0.143 & 0.200 & 0.269 & 0.147 & 0.199 \\
\hline 2005 & 0.072 & 0.112 & -0.041 & 0.207 & 0.238 & 0.153 & 0.316 & 0.140 & 0.186 & 0.302 & 0.132 & 0.185 \\
\hline 2006 & 0.065 & 0.059 & -0.057 & -0.167 & 0.234 & 0.153 & 0.320 & 0.174 & 0.186 & 0.341 & 0.136 & 0.248 \\
\hline 2007 & 0.069 & -0.015 & -0.052 & 0.050 & 0.224 & 0.150 & 0.314 & 0.172 & 0.194 & 0.345 & 0.150 & 0.237 \\
\hline
\end{tabular}


Table A19. ROA, Cash Holdings, and Leverage by Industry.

The unit of observation in this table is a firm-year. For details of the sample construction and variable definitions, see Tables A2 and A9, respectively.

\begin{tabular}{|c|c|c|c|c|c|c|c|c|c|c|c|c|}
\hline & \multicolumn{4}{|c|}{ Mean ROA } & \multicolumn{4}{|c|}{ Mean cash holdings } & \multicolumn{4}{|c|}{ Mean leverage } \\
\hline & \multicolumn{2}{|c|}{ Full sample (F) } & \multicolumn{2}{|c|}{$\begin{array}{l}\text { Matched sample } \\
\text { (M) }\end{array}$} & \multicolumn{2}{|c|}{ Full sample (F) } & \multicolumn{2}{|c|}{$\begin{array}{l}\text { Matched sample } \\
\text { (M) }\end{array}$} & \multicolumn{2}{|c|}{ Full sample (F) } & \multicolumn{2}{|c|}{$\begin{array}{l}\text { Matched sample } \\
\text { (M) }\end{array}$} \\
\hline & Public & Private & Public & Private & Public & Private & Public & Private & Public & Private & Public & Private \\
\hline Food products & 0.145 & 0.105 & 0.110 & 0.140 & 0.092 & 0.107 & 0.127 & 0.031 & 0.262 & 0.399 & 0.198 & 0.264 \\
\hline Beer \& liquor & 0.152 & 0.118 & 0.080 & 0.049 & 0.097 & 0.058 & 0.108 & 0.015 & 0.235 & 0.420 & 0.145 & 0.310 \\
\hline Tobacco products & 0.152 & -0.418 & & & 0.170 & 0.076 & & & 0.365 & 0.935 & & \\
\hline Recreation & 0.109 & 0.096 & 0.073 & 0.164 & 0.151 & 0.163 & 0.212 & 0.095 & 0.313 & 0.410 & 0.231 & 0.339 \\
\hline Printing \& publishing & 0.125 & -0.008 & 0.065 & 0.149 & 0.090 & 0.135 & 0.123 & 0.033 & 0.251 & 0.346 & 0.216 & 0.587 \\
\hline Consumer goods & 0.128 & 0.074 & 0.024 & -0.012 & 0.125 & 0.109 & 0.160 & 0.145 & 0.236 & 0.258 & 0.140 & 0.101 \\
\hline Apparel & 0.177 & 0.406 & 0.138 & 0.278 & 0.149 & 0.088 & 0.165 & 0.189 & 0.150 & 0.194 & 0.080 & 0.064 \\
\hline Healthcare, medical equipment, pharma. prods. & -0.101 & 0.155 & -0.303 & -0.356 & 0.405 & 0.257 & 0.488 & 0.250 & 0.165 & 0.421 & 0.119 & 0.178 \\
\hline Chemicals & 0.071 & 0.049 & -0.156 & 0.152 & 0.131 & 0.081 & 0.290 & 0.045 & 0.251 & 0.311 & 0.134 & 0.338 \\
\hline Textiles & 0.105 & -0.054 & -0.040 & 0.126 & 0.111 & 0.098 & 0.275 & 0.327 & 0.265 & 0.224 & 0.000 & 0.134 \\
\hline Construction and construction materials & 0.122 & 0.111 & 0.064 & 0.117 & 0.121 & 0.130 & 0.188 & 0.052 & 0.249 & 0.260 & 0.225 & 0.325 \\
\hline Steel works Etc & 0.148 & 0.104 & 0.151 & 0.242 & 0.079 & 0.120 & 0.106 & 0.017 & 0.264 & 0.262 & 0.154 & 0.287 \\
\hline Fabricated products and machinery & 0.094 & 0.076 & 0.017 & 0.108 & 0.147 & 0.097 & 0.180 & 0.061 & 0.196 & 0.294 & 0.138 & 0.192 \\
\hline Electrical equipment & 0.013 & 0.054 & -0.144 & 0.168 & 0.164 & 0.122 & 0.202 & 0.174 & 0.232 & 0.243 & 0.239 & 0.053 \\
\hline Automobiles and trucks & 0.105 & 0.092 & 0.009 & 0.095 & 0.106 & 0.100 & 0.129 & 0.012 & 0.237 & 0.315 & 0.202 & 0.184 \\
\hline Aircraft, ships, and railorad equipment & 0.136 & 0.156 & 0.120 & 0.215 & 0.087 & 0.107 & 0.196 & 0.158 & 0.205 & 0.305 & 0.147 & 0.291 \\
\hline Precious metal, non-metallic, ind. metal mining & 0.146 & 0.126 & 0.029 & 0.055 & 0.121 & 0.137 & 0.029 & 0.014 & 0.231 & 0.274 & 0.331 & 0.113 \\
\hline Coal & 0.028 & 0.534 & -0.019 & 0.183 & 0.082 & 0.367 & 0.153 & 0.021 & 0.335 & 0.131 & 0.724 & 0.381 \\
\hline Petroleum and natural gas & 0.194 & 0.444 & 0.146 & 0.382 & 0.085 & 0.168 & 0.132 & 0.087 & 0.268 & 0.283 & 0.267 & 0.295 \\
\hline Communication & 0.077 & 0.113 & -0.064 & 0.668 & 0.131 & 0.161 & 0.264 & 0.096 & 0.409 & 0.448 & 0.181 & 0.412 \\
\hline Personal and business services & 0.064 & 0.110 & -0.024 & 0.140 & 0.311 & 0.185 & 0.339 & 0.195 & 0.140 & 0.285 & 0.124 & 0.183 \\
\hline Business equipment & 0.022 & 0.053 & -0.058 & 0.218 & 0.328 & 0.147 & 0.354 & 0.154 & 0.114 & 0.234 & 0.096 & 0.196 \\
\hline Business supplies and shipping containers & 0.128 & 0.062 & 0.065 & 0.064 & 0.060 & 0.073 & 0.121 & 0.028 & 0.323 & 0.294 & 0.167 & 0.332 \\
\hline Transportation & 0.127 & 0.033 & 0.011 & 0.093 & 0.122 & 0.135 & 0.072 & 0.129 & 0.287 & 0.429 & 0.207 & 0.272 \\
\hline Wholesale & 0.095 & 0.028 & 0.030 & 0.091 & 0.095 & 0.099 & 0.138 & 0.060 & 0.224 & 0.227 & 0.227 & 0.165 \\
\hline Retail & 0.154 & -0.037 & 0.077 & -0.111 & 0.138 & 0.126 & 0.139 & 0.069 & 0.186 & 0.324 & 0.240 & 0.262 \\
\hline Restaurants, hotels, motels & 0.160 & -0.024 & 0.101 & 0.068 & 0.095 & 0.154 & 0.163 & 0.100 & 0.267 & 0.573 & 0.236 & 0.585 \\
\hline Everything else & 0.140 & 0.070 & 0.139 & 0.092 & 0.103 & 0.104 & 0.127 & 0.041 & 0.312 & 0.295 & 0.254 & 0.192 \\
\hline
\end{tabular}


Table A20. ROA, Cash Holdings, and Leverage by State.

For details of the sample construction and variable definitions, see Tables A2 and A9, respectively.

\begin{tabular}{|c|c|c|c|c|c|c|c|c|c|c|c|c|}
\hline & \multicolumn{4}{|c|}{ Mean ROA } & \multicolumn{4}{|c|}{ Mean cash holdings } & \multicolumn{4}{|c|}{ Mean leverage } \\
\hline & \multicolumn{2}{|c|}{ Full sample (F) } & \multicolumn{2}{|c|}{$\begin{array}{l}\text { Matched sample } \\
\text { (M) }\end{array}$} & \multicolumn{2}{|c|}{ Full sample (F) } & \multicolumn{2}{|c|}{$\begin{array}{l}\text { Matched sample } \\
\text { (M) }\end{array}$} & \multicolumn{2}{|c|}{ Full sample (F) } & \multicolumn{2}{|c|}{$\begin{array}{l}\text { Matched sample } \\
\text { (M) }\end{array}$} \\
\hline & Public & Private & Public & Private & Public & Private & Public & Private & Public & Private & Public & Private \\
\hline AK & 0.171 & -0.062 & & & 0.060 & 0.206 & & & 0.664 & 0.240 & & \\
\hline $\mathrm{AL}$ & 0.128 & 0.172 & 0.020 & 0.011 & 0.179 & 0.169 & 0.287 & 0.034 & 0.174 & 0.388 & 0.065 & 0.174 \\
\hline AR & 0.177 & 0.364 & 0.143 & 4.798 & 0.049 & 0.158 & 0.026 & 0.093 & 0.273 & 0.391 & 0.289 & 0.000 \\
\hline $\mathrm{AZ}$ & 0.132 & 0.177 & 0.038 & 0.070 & 0.206 & 0.151 & 0.247 & 0.062 & 0.239 & 0.267 & 0.101 & 0.417 \\
\hline CA & -0.009 & 0.007 & -0.153 & -0.705 & 0.362 & 0.163 & 0.427 & 0.371 & 0.132 & 0.243 & 0.108 & 0.160 \\
\hline $\mathrm{CO}$ & 0.067 & 0.307 & -0.014 & 0.420 & 0.201 & 0.169 & 0.246 & 0.054 & 0.218 & 0.342 & 0.151 & 0.357 \\
\hline CT & 0.080 & -0.010 & -0.059 & 0.155 & 0.208 & 0.156 & 0.297 & 0.076 & 0.248 & 0.326 & 0.182 & 0.135 \\
\hline DC & 0.089 & 0.314 & & & 0.172 & 0.192 & & & 0.210 & 0.324 & & \\
\hline $\mathrm{DE}$ & -0.050 & 0.111 & -0.365 & 0.022 & 0.213 & 0.122 & 0.276 & 0.072 & 0.304 & 0.301 & 0.105 & 1.197 \\
\hline FL & 0.071 & 0.135 & -0.004 & -0.044 & 0.141 & 0.175 & 0.177 & 0.171 & 0.243 & 0.357 & 0.196 & 0.178 \\
\hline GA & 0.101 & 0.136 & 0.021 & 0.326 & 0.165 & 0.162 & 0.214 & 0.154 & 0.241 & 0.368 & 0.194 & 0.124 \\
\hline $\mathrm{HI}$ & -0.135 & -0.055 & -0.323 & -0.247 & 0.132 & 0.167 & 0.168 & 0.039 & 0.151 & 0.226 & 0.111 & 0.412 \\
\hline IA & 0.170 & 0.094 & 0.162 & 0.005 & 0.108 & 0.126 & 0.052 & 0.159 & 0.222 & 0.351 & 0.244 & 0.261 \\
\hline ID & 0.029 & 0.153 & -0.489 & 0.102 & 0.199 & 0.108 & 0.220 & 0.004 & 0.180 & 0.279 & 0.295 & 0.774 \\
\hline IL & 0.103 & 0.014 & -0.070 & 0.062 & 0.155 & 0.157 & 0.273 & 0.161 & 0.220 & 0.323 & 0.155 & 0.117 \\
\hline IN & 0.156 & 0.041 & 0.133 & 0.228 & 0.126 & 0.142 & 0.104 & 0.056 & 0.194 & 0.321 & 0.154 & 0.429 \\
\hline KS & 0.148 & 0.101 & 0.054 & 0.204 & 0.156 & 0.143 & 0.251 & 0.118 & 0.170 & 0.347 & 0.130 & 0.212 \\
\hline KY & 0.165 & -0.030 & 0.200 & 0.267 & 0.080 & 0.151 & 0.064 & 0.104 & 0.232 & 0.314 & 0.238 & 0.109 \\
\hline LA & 0.177 & 0.397 & 0.217 & 0.347 & 0.090 & 0.171 & 0.164 & 0.018 & 0.266 & 0.331 & 0.231 & 0.201 \\
\hline MA & -0.024 & -0.002 & -0.139 & 0.061 & 0.373 & 0.158 & 0.442 & 0.109 & 0.131 & 0.309 & 0.090 & 0.175 \\
\hline MD & 0.006 & 0.087 & -0.090 & -0.094 & 0.277 & 0.170 & 0.354 & 0.098 & 0.175 & 0.246 & 0.128 & 0.213 \\
\hline ME & 0.139 & -0.030 & 0.092 & & 0.275 & 0.136 & 0.268 & & 0.109 & 0.278 & 0.026 & \\
\hline MI & 0.106 & -0.039 & -0.038 & 0.106 & 0.149 & 0.126 & 0.232 & 0.077 & 0.231 & 0.296 & 0.152 & 0.345 \\
\hline MN & 0.102 & 0.020 & 0.044 & 0.238 & 0.216 & 0.125 & 0.250 & 0.081 & 0.148 & 0.375 & 0.118 & 0.409 \\
\hline MO & 0.145 & 0.084 & 0.060 & 0.237 & 0.093 & 0.128 & 0.140 & 0.049 & 0.254 & 0.345 & 0.186 & 0.112 \\
\hline MS & 0.188 & 0.339 & 0.151 & 0.009 & 0.104 & 0.219 & 0.101 & 0.104 & 0.308 & 0.336 & 0.339 & 0.002 \\
\hline MT & 0.062 & 0.231 & & & 0.204 & 0.134 & & & 0.099 & 0.358 & & \\
\hline $\mathrm{NC}$ & 0.076 & 0.075 & -0.050 & 0.504 & 0.180 & 0.155 & 0.272 & 0.146 & 0.248 & 0.365 & 0.172 & 0.429 \\
\hline
\end{tabular}


Table A20. Continued.

\begin{tabular}{|c|c|c|c|c|c|c|c|c|c|c|c|c|}
\hline & \multicolumn{4}{|c|}{ Mean ROA } & \multicolumn{4}{|c|}{ Mean cash holdings } & \multicolumn{4}{|c|}{ Mean leverage } \\
\hline & \multicolumn{2}{|c|}{ Full sample (F) } & \multicolumn{2}{|c|}{$\begin{array}{l}\text { Matched sample } \\
\text { (M) }\end{array}$} & \multicolumn{2}{|c|}{ Full sample (F) } & \multicolumn{2}{|c|}{$\begin{array}{l}\text { Matched sample } \\
\text { (M) }\end{array}$} & \multicolumn{2}{|c|}{ Full sample (F) } & \multicolumn{2}{|c|}{$\begin{array}{l}\text { Matched sample } \\
\text { (M) }\end{array}$} \\
\hline & Public & Private & Public & Private & Public & Private & Public & Private & Public & Private & Public & Private \\
\hline ND & 0.182 & 0.161 & 0.201 & & 0.052 & 0.173 & 0.059 & & 0.149 & 0.200 & 0.150 & \\
\hline $\mathrm{NE}$ & 0.148 & -0.015 & 0.067 & 0.194 & 0.138 & 0.131 & 0.213 & 0.210 & 0.206 & 0.311 & 0.130 & 0.108 \\
\hline NH & 0.067 & -0.082 & -0.076 & -0.077 & 0.133 & 0.147 & 0.108 & 0.317 & 0.155 & 0.343 & 0.190 & 0.056 \\
\hline $\mathrm{NJ}$ & -0.001 & 0.049 & -0.185 & -0.007 & 0.266 & 0.159 & 0.338 & 0.125 & 0.212 & 0.266 & 0.189 & 0.188 \\
\hline NM & -0.027 & 0.096 & 0.095 & 0.008 & 0.254 & 0.153 & 0.272 & 0.400 & 0.301 & 0.337 & 0.000 & 0.026 \\
\hline NV & 0.139 & 0.160 & 0.148 & 0.396 & 0.126 & 0.173 & 0.159 & 0.115 & 0.461 & 0.242 & 0.413 & 0.300 \\
\hline NY & 0.059 & 0.029 & -0.062 & 0.082 & 0.227 & 0.154 & 0.282 & 0.156 & 0.192 & 0.277 & 0.120 & 0.132 \\
\hline $\mathrm{OH}$ & 0.131 & 0.039 & 0.079 & 0.089 & 0.096 & 0.146 & 0.182 & 0.064 & 0.242 & 0.260 & 0.188 & 0.309 \\
\hline OK & 0.173 & 0.219 & 0.166 & 0.191 & 0.073 & 0.151 & 0.104 & 0.033 & 0.286 & 0.335 & 0.221 & 0.250 \\
\hline OR & 0.068 & 0.077 & -0.047 & 0.148 & 0.245 & 0.148 & 0.298 & 0.068 & 0.213 & 0.230 & 0.126 & 0.225 \\
\hline $\mathrm{PA}$ & 0.085 & 0.057 & -0.091 & 0.569 & 0.209 & 0.146 & 0.390 & 0.118 & 0.226 & 0.276 & 0.146 & 0.228 \\
\hline RI & 0.104 & 0.025 & 0.025 & -0.945 & 0.167 & 0.155 & 0.191 & 0.083 & 0.175 & 0.218 & 0.082 & 0.121 \\
\hline SC & 0.119 & 0.020 & 0.175 & 0.230 & 0.146 & 0.182 & 0.168 & 0.222 & 0.184 & 0.387 & 0.046 & 0.058 \\
\hline SD & 0.332 & 0.166 & 0.334 & & 0.091 & 0.152 & 0.123 & & 0.402 & 0.248 & 0.024 & \\
\hline $\mathrm{TN}$ & 0.168 & 0.057 & 0.127 & 0.202 & 0.108 & 0.136 & 0.060 & 0.196 & 0.261 & 0.317 & 0.315 & 0.245 \\
\hline $\mathrm{TX}$ & 0.127 & 0.096 & 0.034 & 0.170 & 0.138 & 0.153 & 0.199 & 0.092 & 0.250 & 0.339 & 0.255 & 0.296 \\
\hline UT & 0.119 & 0.229 & 0.101 & 0.341 & 0.268 & 0.178 & 0.298 & 0.144 & 0.139 & 0.244 & 0.117 & 0.182 \\
\hline VA & 0.080 & 0.102 & -0.084 & 0.097 & 0.167 & 0.153 & 0.253 & 0.058 & 0.188 & 0.308 & 0.132 & 0.182 \\
\hline VT & 0.147 & 0.065 & 0.143 & 0.170 & 0.093 & 0.112 & 0.144 & 0.174 & 0.345 & 0.414 & 0.359 & 0.000 \\
\hline WA & -0.025 & 0.099 & -0.176 & 0.227 & 0.336 & 0.166 & 0.363 & 0.087 & 0.186 & 0.365 & 0.156 & 0.189 \\
\hline WI & 0.132 & 0.000 & -0.008 & 0.074 & 0.123 & 0.134 & 0.239 & 0.042 & 0.180 & 0.294 & 0.075 & 0.239 \\
\hline WV & 0.152 & 0.124 & 0.193 & 0.145 & 0.100 & 0.140 & 0.154 & 0.049 & 0.250 & 0.382 & 0.126 & 0.863 \\
\hline WY & 0.161 & 0.306 & 0.157 & 0.039 & 0.052 & 0.159 & 0.073 & 0.011 & 0.106 & 0.404 & 0.068 & 0.148 \\
\hline Other & -0.042 & & -0.029 & & 0.265 & & 0.294 & & 0.151 & & 0.096 & \\
\hline
\end{tabular}


Table A21. ROA, Cash Holdings, and Leverage by Legal Form of Organization.

The unit of observation in this table is a firm-year. For details of the sample construction and variable definitions, see Tables A2 and A9, respectively.

\begin{tabular}{|c|c|c|c|c|c|c|c|c|c|c|c|c|}
\hline & \multicolumn{4}{|c|}{ Mean ROA } & \multicolumn{4}{|c|}{ Mean cash holdings } & \multicolumn{4}{|c|}{ Mean leverage } \\
\hline & \multicolumn{2}{|c|}{ Full sample (F) } & \multicolumn{2}{|c|}{$\begin{array}{l}\text { Matched sample } \\
\text { (M) }\end{array}$} & \multicolumn{2}{|c|}{ Full sample (F) } & \multicolumn{2}{|c|}{$\begin{array}{l}\text { Matched sample } \\
\text { (M) }\end{array}$} & \multicolumn{2}{|c|}{ Full sample (F) } & \multicolumn{2}{|c|}{$\begin{array}{l}\text { Matched sample } \\
\text { (M) }\end{array}$} \\
\hline & Public & Private & Public & Private & Public & Private & Public & Private & Public & Private & Public & Private \\
\hline C Corps & 0.065 & -0.089 & -0.060 & 0.005 & 0.226 & 0.138 & 0.304 & 0.176 & 0.199 & 0.278 & 0.149 & 0.198 \\
\hline S Corps & & 0.142 & & 0.179 & & 0.158 & & 0.109 & & 0.316 & & 0.236 \\
\hline Sole proprietorships & & 0.661 & & 0.185 & & 0.186 & & 0.218 & & 0.363 & & 0.056 \\
\hline Limited liability companies (LLC) & & 0.228 & & 0.371 & & 0.137 & & 0.075 & & 0.403 & & 0.368 \\
\hline Partnerships & 0.168 & 0.329 & 0.257 & 0.362 & 0.032 & 0.174 & 0.048 & 0.066 & 0.412 & 0.466 & 0.369 & 0.299 \\
\hline Limited liability partnerships (LLP) & & 0.436 & & 0.204 & & 0.205 & & 0.277 & & 0.335 & & 0.155 \\
\hline Other & & 0.110 & & 0.122 & & 0.252 & & 0.232 & & 0.230 & & 0.197 \\
\hline
\end{tabular}

